
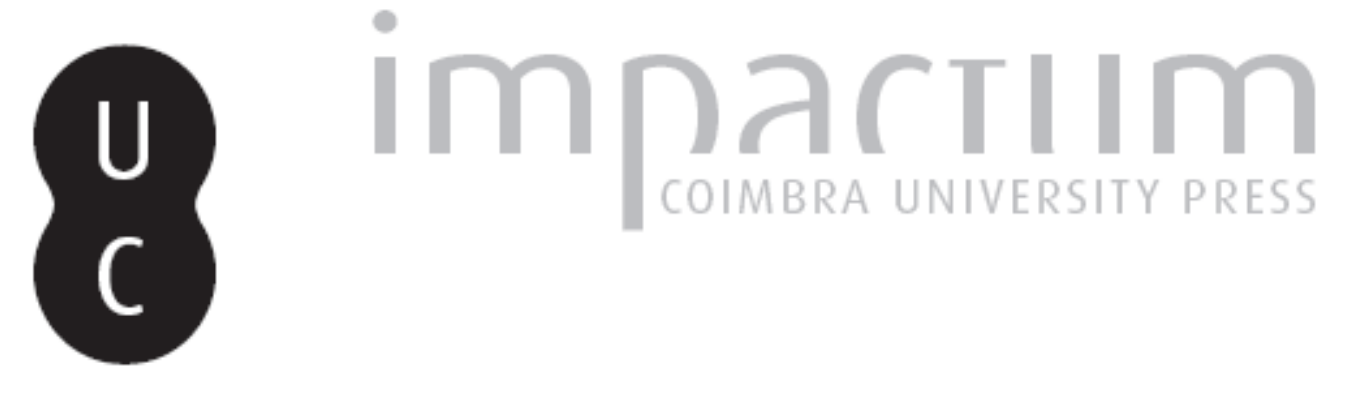

\title{
O problema xxx e o tratamento da condição melancólica em Aristóteles
}

\author{
Autor(es): $\quad$ Carvalho, Cláudio Alexandre S.
}

Publicado por: Faculdade de Letras da Universidade de Coimbra, Instituto de Estudos

URL persistente:

URI:http://hdl.handle.net/10316.2/37872

DOI:

DOl:http://dx.doi.org/10.14195/0872-0851_47_2

Accessed : $\quad$ 26-Apr-2023 11:21:19

A navegação consulta e descarregamento dos títulos inseridos nas Bibliotecas Digitais UC Digitalis, UC Pombalina e UC Impactum, pressupõem a aceitação plena e sem reservas dos Termos e Condições de Uso destas Bibliotecas Digitais, disponíveis em https://digitalis.uc.pt/pt-pt/termos.

Conforme exposto nos referidos Termos e Condições de Uso, o descarregamento de títulos de acesso restrito requer uma licença válida de autorização devendo o utilizador aceder ao(s) documento(s) a partir de um endereço de IP da instituição detentora da supramencionada licença.

Ao utilizador é apenas permitido o descarregamento para uso pessoal, pelo que o emprego do(s) título(s) descarregado(s) para outro fim, designadamente comercial, carece de autorização do respetivo autor ou editor da obra.

Na medida em que todas as obras da UC Digitalis se encontram protegidas pelo Código do Direito de Autor e Direitos Conexos e demais legislação aplicável, toda a cópia, parcial ou total, deste documento, nos casos em que é legalmente admitida, deverá conter ou fazer-se acompanhar por este aviso.

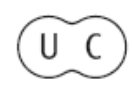




\section{REVISTA FILOSÓFICA COIMBRA}

vol. 24 - número 47- março 2015

vol. 24 - número 47- março 2015

Fundação Eng. António de Almeida

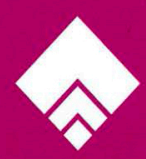




\title{
O PROBLEMA XXX E O TRATAMENTO DA CONDIÇÃO MELANCÓLICA EM ARISTÓTELES.
}

\author{
CLÁUdiO ALEXANDRE S. CARVALHO*
}

Resumo: O Problema $X X X$ foi objecto de múltiplas interpretações suscitadas pelo seu pressuposto basilar segundo o qual todos homens capazes de performances excepcionais teriam em comum o facto de serem melancólicos. No artigo presente explora-se a ideia de que tal tese, em grande medida inédita e em descontinuidade com a obra de Aristóteles, dá a ler certos princípios da abordagem terapêutica da condição melancólica. De modo congruente com a obra aristotélica, a forma trivial de melancolia - congénita ou adquirida - afecta as faculdades perceptivas, cognitivas e morais, sendo origem de perturbações do comportamento e sofrimento mental. Tal condição, que remete para um excesso de bílis negra sendo abordada sem sistematicidade em vários pontos do Corpus Aristotelicum, requer medidas profiláticas pois suas variantes letais são assintomáticas e de manifestação súbita. Já enquanto condição crónica exige constante vigilância relativamente àquilo que poderá afectar um equilíbrio sempre sob ameaça. No presente artigo mostra-se como essa observação terapêutica do melancólico segue a fixação de um quadro nosológico alternativo ao das teorias médicas constantes do Corpus Hippocraticum, ainda que mantenha com o mesmo afinidades genéricas, nomeadamente quanto aos modos de reequilibrar a mistura (krasis) dos humores, explorando as potencialidades do organismo e das substâncias. Algumas divergências podiam ser já encontradas nos diálogos platónicos onde o método hipocrático de análise da natureza humana é elogiado. Aristóteles e o autor dos Problemata Physica apresentam uma caracterologia do temperamento que se tece através de analogias várias com a ética, em especial com o tema da constituição e aperfeiçoamento do carácter, o qual permaneceu na orla da psicoterapêutica e da psicagogia antigas. A ideia de que uma constituição instável e conotada com padecimentos vários seja a condição para atingir a genialidade, parte de carac-

* Bolseiro de Pós-Doutoramento da Unidade I\&D LIF - Linguagem, Interpretação, Filosofia, linha de investigação: Individuação da Sociedade Moderna (Universidade de Coimbra). Email: kraftcasc@gmail.com. 
terísticas "ethopoieticas" conjugadas num excepcional equilíbrio fisiológico. A par do inquérito em torno da potencialidade das substâncias e da problemática divisão entre o são e o patológico, o tema do papel do observador do equilíbrio fisiológico, emocional e ético permanece latente ao longo do Problema $X X X$ e surge em várias observações do próprio Aristóteles. A não sobrevivência de um texto dedicado em particular à medicina, o Iatrika, torna o Problema $X X X$ num documento essencial para estabelecer as pontes necessárias entre a physike, atida à teorização da biologia dos seres vivos e a iatrikē cuja prioridade é o restabelecimento individual por meio de métodos de intervenção no equilíbrio do corpo.

Palavras-chave: Filosofia médica; Melancolia; Terapia; Eukrasia; Génio.

\begin{abstract}
Problem $X X X$ was object of various interpretations raised mostly by its basic presupposition according to which all men capable of extraordinary performances were melancholic. In the present work, we draw on the idea that such thesis, mostly unprecedented and discontinue with Aristotle's work, provides a reading of certain principles of the therapeutic approach towards the melancholic condition. In accordance with the Aristotelian oeuvre, the trivial forms of melancholy, congenial or acquired, disturb perceptive, cognitive and moral faculties, being source of behavioural disturbances and mental suffering. Such condition, characterized by an excess of black bile is approached in a non-systematic way along the Corpus Aristotelicum, requires prophylactic measures since its lethal variants are asymptomatic and abrupt, but as a chronic condition it demands constant surveillance toward what can affect an always-threatened balance. The present article shows how such therapeutic observation of the melancholic follows the founding of a nosologic framework, alternative to the medical theories affiliated with the Corpus Hippocraticum, despite holding some generic affinities with some of its treatises, concerning ways to reset the mixture (krasis) of humours by exploring the potentialities of the organism and the qualities of the substances. Some divergences could already be found in the platonic dialogues, where the Hippocratic method of analysis of human nature is praised. Aristotle like the author of Problemata Physica presented a classification of temperaments weaved through various analogies with ethics, and especially with the theme of the constitution and perfecting of character, that will remain at the edge of psychotherapy and psychagogy along antiquity. The idea of a constitution considered instable and associated with various illnesses as the condition to achieve geniality, departs from "ethopoietic" characteristics aligned in an exceptional physiological balance. Along with inquiry on the potentiality of substances and the problematic division between health and pathology, the theme of the observer of the physiological, emotional and moral equilibrium remains latent along Problem XXX, and appears in different Aristotle's writings. Given the loss of a text presumably devoted to medical themes, 'Iatrika, turns Problem XXX a document essential to bridge between phusike, concerned with theorizing of living
\end{abstract}


being's biology and iatrike whose priority is assist and reestablish the individual through methods of intervention in bodily equilibrium.

Keywords: Medical Philosophy, Melancholy, Therapy, Eukrasia, Genius.

Por força da sua assunção inicial, de acordo com a qual todos os homens excepcionais são melancólicos, o texto aristotélico sobre a melancolia fascinou diversos intérpretes que notaram a frequência com que o génio se aproxima do limiar da sanidade. Orbitando em torno desse motivo maior, as concepções menos arrojadas da secção 1 do Problema $X X X$ - sobretudo atinentes às oscilações na disposição do melancólico - percorreram um longo trajecto na história das ideias com repercussões ao nível da ética, da psicologia, da estética e da política. Ao mesmo tempo, aquela ideia heterodoxa, ainda que em contacto com o fundo conceptual da historiografia médica da antiguidade, contribuiu para contrabalançar abordagens positivistas dos conceitos médicos, demasiado ocupadas em contar uma história de "sucessos" e mostrar, à luz do saber biomédico moderno, como os antigos gregos estavam no caminho certo. Sob tal afã, essas narrativas esquecem que muitas daquelas que hoje poderíamos ver como interpretações há muito desacreditadas, decorriam de uma lógica própria dificilmente conformável aos pressupostos, método e finalidades da medicina moderna.

Uma crítica paralela pode ser avançada relativamente à abordagem estritamente filológica que por vezes não atendeu ao modo como aquela lógica e seus conceitos são indissociáveis da observação empírica, ordenada de acordo com critérios racionais que não podem ser desvinculados do complexo sociocultural, económico e religioso que os enforma. Assim, deve reconhecer-se de antemão que o estudo deste domínio não canónico, que convocou de modo ocasional a história da medicina, da filosofia e os estudos clássicos, e que nas últimas décadas assistiu a assinaláveis progressos, nos interpela e solicita mais que uma reprodução acrítica, o levantamento de questões que continuam relevantes em variados âmbitos do debate sobre a concepção de saúde pública, nomeadamente, os pressupostos comunicativos subjacentes à relação clínica e, com especial pertinência no aprofundamento do tema de que aqui nos ocupamos, o impacto dos avanços biomédicos na nossa compreensão do homem como ser de "cura e cultura"l.

1 Remeto aqui para o programa interpretativo proposto por Peter Sloterdijk em $D u$ musst dein Leben ändern. Über Anthropotechnik (Frankfurt: Suhrkamp, 2009), esp. 424 e ss. 


\section{Observações acerca da doença mental na Grécia antiga. Proble- mas do contexto social, científico e literário.}

O Problema XXX é bem exemplificativo da necessidade de precisar aquilo que se entende por "racional" quando esse qualificativo é utilizado para caracterizar a especificidade da medicina grega. Investigações da antropologia médica confirmam sem margem para dúvidas a existência de práticas médicas entre civilizações do Mediterrâneo oriental, em particular a babilónica e a egípcia, e nalguns casos é possível encontrar uma continuidade e influência de algumas concepções e práticas sobre o saber médico grego ${ }^{2}$. Mas o que distingue a constituição deste saber é o facto de o mesmo estar assente numa propensão inédita para considerar a doença a partir de fundamentos epistémicos que permitem indicar os sinais da patologia, estabelecer ou pelo menos levantar hipóteses quanto às suas causas, antecipar as suas manifestações essenciais e secundárias e propor tratamentos eficazes ${ }^{3}$. Tais fundamentos epistémicos não isentam aqueles cultores da medicina de explicações aberrantes que, não obstante coerentes com o modelo lógico subjacente, por vezes impõem crenças enraizadas na cultura grega, relacionadas com valorações morais de certos elementos ou características ${ }^{4}$. É certo que devido à gradual transição da cultura oral para a mediação escrita, e tidos em conta os diversos objectivos a que essa transição responde ${ }^{5}$, começa a diluir-

2 Ver a título de exemplo a colectânea editada por H. F. J. Horstmanshoff e M. Stol: Magic and Rationality in Ancient Near Eastern and Graeco-Roman Medicine (Leiden: Brill, 2004), a "Introdução" da mesma, a cargo de Philip J. van der Eijk, seguida de bibliografia para o estudo comparativo da medicina grega com civilizações do Antigo Oriente.

$3 \mathrm{Um}$ dos aspectos que vem a diferenciar as perspectivas médico-terapêuticas contidas no $\mathrm{CH}$, parte inerente da sua eficácia, é justamente o evitar de métodos terapêuticos desnecessariamente dolorosos.

4 Veja-se por exemplo, a propósito da arreigada divisão sexual o amplo estudo que suporta a tese de Helen King: "entre o conflitual âmbito de imagens do corpo feminino fornecido no corpus existia uma tradição desse corpo que o via como radicalmente diferente do masculino, comportando-se de modos distintos e requerendo terapias diferentes". Id. Hippocrates' Woman. Reading the female body in Ancient Greece (London and New York: Routledge, 1998), 11.

5 A lavra de textos corresponde a intenções diversas que vão além da divulgação ou universalização de saberes teóricos e práticos, sendo contudo evidente a tendência à uniformização de procedimentos. À luz da leitura de textos como os Epidémicos é evidente a importância do registo casuístico e notas que, antecipando a moderna a abordagem estatística, facilitam o estudo comparativo de doenças e permitem por exemplo discernir os traços característicos que distinguem a origem e manifestação da doença em cada um dos tipos de compleição natural. De modo distinto, alguns textos teriam por objectivo maior auxiliar a memória em determinados pontos do processo clínico, como é evidente no caso da confecção de fármacos. 
-se muita da densidade da relação mestre discípulo essencial à formação que caracterizava a unidade das comunidades médicas, mas também a referência à dimensão divina e demonológica da doença.

Nos textos hipocráticos encontramos diversos exemplos de tais "erros" peculiares da medicina antiga, mas é possível afirmar que os Problemata, devido à conjugação de duas filiações, a médica e a aristotélica, mais que concepções erróneas apresentaram teorias cuja exuberância tornou muitas vezes difícil sua assimilação. Na recepção ao Problema $X X X$, em especial na sua primeira secção, a dificuldade atingiu tanto o saber médico, que perante a valorização de certos sintomas da melancolia vê esvanecerem-se os contornos da semiologia patológica, como o saber filosófico, forçado a atender ao complexo nexo entre a compleição física (congénita) e a doença, e em ambas ter em conta as dinâmicas do temperamento, dos traços de carácter moral e da aptidão para aceder a certos domínios especulativos.

Mais do que campos disciplinares estanques falamos de "áreas de actividade" que têm frequentemente procedimentos metodológicos comuns e se sobrepõem ao nível terminológico, sendo que a partilha do contexto sociocultural implica a sua correspondência a problemas comuns que a sociedade selecionava como relevantes e em certa medida indicativos da sua organização, sendo isso notório na perturbação mental. É justamente sobre o padecimento mental que cada uma das áreas de actividade desenvolverá etiologias, semiologias e terapêuticas próprias, as comunidades médicas através de uma compreensão do desequilíbrio ou falha fisiológica tout court, e as escolas filosóficas tomando-a como "doença da alma" e privilegiando o domínio mental na origem da perturbação, adoptando o exame de crenças, emoções e representações, ainda que concedendo a existência de um domínio físico do desequilíbrio.

Comidas, bebidas e drogas podem produzir, de acordo com as especificidades da manifestação e curso da doença no paciente, benefícios na condição corpórea. Tais benefícios podem ser atestados mesmo quando as descrições de seus efeitos são fantasiosas ${ }^{6}$ ou não é evidente o modo de acção daqueles agentes, diríamos hoje, o seu princípio activo. Muitas das vezes a farmacopeia fixou e transmitiu usos terapêuticos cujo mecanismo de acção só seria devidamente explicado com referência às reacções químicas da substância

${ }^{6}$ Este tema tem especial relevância na diferenciação patente em textos como o $D a$ Medicina Antiga onde está claramente em questão a necessidade de uma diferenciação entre o método médico e a chamada medicina do templo, práticas que partilham a veneração por um ascendente comum, Asclépio, cf. Maria Elena Gorrini, "The Hippocratic Impact on Healing Cults: the archeological evidence in Attica" in Hippocrates in Context, ed. Philip J. van der Eijk (Leiden/Boston: Brill, 2005), 141-147. 
activa de determinada planta ou composto ${ }^{7}$. Ao mesmo tempo, a ausência do conhecimento dos processos mas também do isolamento da substância activa faz com que certos fármacos, utilizados no restabelecimento ou no alívio de vários sintomas, tenham efeitos secundários consideravelmente nocivos. Algo similar ocorre com a prescrição de determinados tipos de regime.

A Medicina e a Filosofia antigas têm a sua respectiva autonomia sedimentada em ligamentos semânticos fortes, centrados nos conceitos gerais de equilíbrio e integridade, conceitos que assumem em cada um dos domínios uma operatividade própria mas aberta a influências, cruzamentos e derivações. Contudo, suas vocações distintas permitem bem mais que o esboçar de esquemas de analogias, mais ou menos pertinentes e precisos entre o diagnóstico médico da doença e o exame de crenças e raciocínio facilitado ou promovido pelo filósofo. E mesmo se os médicos se demitiram da abordagem de dimensões éticas e religiosas, as ideias literárias e quotidianas da doença, em particular da doença mental tão difundida na tragédia ${ }^{8}$, serviram de pauta à sua abordagem, determinando desde logo aquela que seria sua distinção primária entre o patológico e o não-patológico. Isto é, a dimensão social do cuidado terapêutico é legível desde logo pelo binómio consideração vs. indiferença relativamente a uma dada condição física, mental ou comportamental do indivíduo?.

Apesar da sua contribuição inequívoca para a interpretação da filosofia antiga, algumas das teses de autores que a exemplo de Edelstein, avaliaram a relação entre filosofia e medicina, foram largamente infirmadas. É esse o caso da defesa de que filosofia grega não foi influenciada pelas investigações e teorias médicas ${ }^{10}$. É hoje consensual que a observação médica serviu fre-

7 Ver a este respeito o estudo de John Scarborough quanto à eficácia dos antigos unguentos, no qual concluiu ser possível dividir claramente entre aqueles de origem vegetal, quase sempre com propriedades terapêuticas, e os derivados de origem animal, também presentes em rituais catárticos mas sem qualquer evidência de cura, cf. Id. "The Pharmacology of Sacred Plants, Herbs, and Roots" in Magika Hiera. Ancient Greek Magic and Religion, eds. Christopher A. Faraone and Dirk Obbink (New York: Oxford University Press, 1991), 138-174.

8 Além de Medeia cuja humilhação leva um estado melancólico extremo, na tragédia clássica encontramos diversos exemplos de loucura, sobretudo por via da possessão ou vingança divina, são exemplos Orestes tomado pelas Fúrias, mas também: Ajáx, Penteus e Héracles.

9 Neste mesmo âmbito é necessário tomar em linha de conta o facto de que na Grécia antiga o acesso a cuidados de saúde estava inequivocamente dependente da origem e estatuto social dos indivíduos. O mesmo ocorria no acesso a uma comunidade filosófica ou médica, cf. Guenter B. Risse, Mending Bodies, Saving Souls. A history of Hospitals (New York: Oxford University Press: 1999), 15-38.

10 Cf. Ludwig Edelstein, Ancient medicine: Selected papers of Ludwig Edelstein, eds. 
quentemente de modelo à observação e teorização da pv́ఠıৎ como modelo de semeiologia ${ }^{11}$. Outras teses foram sujeitas a profunda revisão, nomeadamente a de que a medicina só obtém um corpo de saber sistemático e autónomo por via da contribuição do pensamento filosófico ${ }^{12}$. Mas se nos aparece como inequívoca a influência mútua entre as investigações filosóficas e a prática médica, a verdade é que por um lado grande parte da medicina empírica e "metódica" se manteve céptica relativamente à eficácia da cura proposta pelos filósofos, por outro, as teorias subjacentes à terapia, sobretudo a doutrina dos humores, não foram admitidas pelas escolas filosóficas sem resistências e cepticismos de diversa ordem bem como com a contraposição de alternativas. O Problema XXX constitui-se no cruzamento entre essas dificuldades de conciliação.

Além de um infindável conjunto de observações e descrições de procedimentos práticos, os escritos médicos da antiguidade clássica, de Hipócrates a Alexandre de Trales, fornecem-nos, mesmo antes do auge do pensamento filosófico, um conjunto de teorias e conceitos direccionados para a compreensão da causalidade orgânica. Importante para a compreensão da melancolia em particular é a ideia de correlação entre uma compleição física e, por força de circunstâncias particulares do meio do indivíduo, o surgimento de formas de padecimento eminentemente mental. Desde aqueles que a investigação histórico-filológica apontou como os primeiros escritos do Corpus Hippocraticum $[\mathrm{CH}]$, se verificava uma atenção dos antigos médicos relativamente à potencialidade de determinadas substâncias, não só as constituintes do organismo (ou interiores), as responsáveis pela sua subsistência e florescimento, bem como aquelas que em caso de patologias seriam recomendáveis por forma a restabelecer o bem-estar corporal e psíquico. Tais observações sistemáticas, ainda que frequentemente conflituais e ambíguas, dos mecanismos causais na origem das perturbações (etiologia), da subsistência e do restabelecimento do corpo humano, têm subjacente um conceito fundamental, o de eficácia. É possível afirmar que este conceito, assumindo

Owsei Temkin \& C. Lilian Temkin (Baltimore: the Johns hopkins Press, 1967 [1952]), 349-351.

11 "O que a medicina tinha a oferecer tanto à filosofia como à historiografia era um modelo semiótico de saber que operava ao nível de uma estrutura formal sólida (logismós, ou seja, raciocínio inferencial no modo dedutivo e abdutivo) e com uma orientação empírica básica (...). [O] sinal médico é o produto de um raciocínio inferencial aplicado aos fenómenos recorrentes que adquirem sentido, e portanto se tornam sinais, pelo facto de que podem ser rastreados de volta ao logismós". Giovanni Manetti, Theories of the Sign in Classical Antiquity, trans. Christine Richardson (Bloomington and Indianapolis: Indiana University Press, 1993[1987]), 37.

12 Cf. Edelstein, Ancient medicine, 354. 
conotações várias que vão da ideia de uma atestação da melhoria da condição patológica até às concepções que daí reclamaram propiciar a integridade da comunidade, subjaz a todas as escolas, correntes ou comunidades de praticantes que se arroguem o epíteto de terapêuticas. As ideias de moderação das escolas da Grécia clássica bem como do helenismo raramente se debruçaram abertamente sobre o estado melancólico, contudo muitas das atitudes e exercícios que propunham, bem mais próximos do religioso do que do científico ou filosófico contemporâneo, podem ser tomados como eminentemente profiláticos do estado depressivo. Além da demarcação de rituais religiosos, a consideração eminentemente orgânica da melancolia permitiu fixar critérios que fundamentam a distinção entre o patológico e uma grande variedade de infortúnios inerentes à condição humana ${ }^{13}$.

Uma vez que aos factores inerentes ao temperamento (os "res naturales" expostos por Galeno) estava associada uma certa rigidez e imutabilidade, recairá nos factores ditos "não naturais" (relativos ao meio físico, ao exercício, ao sono-vigília, à dieta, à excreção-retenção e às paixões) a possibilidade de influir positivamente no restabelecimento. $\mathrm{O}$ mesmo equivale a dizer que, em grande parte das maleitas a função do médico consistia em prescrever e reforçar a correcta administração daqueles elementos que surgem associados

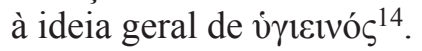

\section{Acepções e funções da metáfora médica}

É neste contexto aqui brevemente sintetizado que têm lugar as explicações da melancolia, desde o aventar de que uma substância em excesso origina uma constelação mutável de sintomas persistentes com incidência na

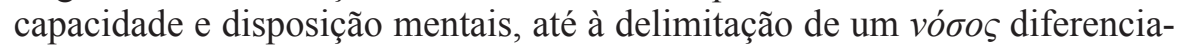
do. A abordagem criteriosa do corpo humano e do seu meio que encontramos nos escritos médicos não impediu, também por força de circunstancialismos religiosos e culturais, que toda a ideia de melancolia se tenha apoiado no pressuposto da existência de uma substância homónima cuja abundância no organismo ou a desregulação de outros factores como o calor e a humidade são considerados a origem de perturbações mentais. Tais perturbações vão da

13 Ainda assim, como se torna claro na filosofia de pendor terapêutico dedicada às doenças da alma, verifica-se a resistência à patologização de certos estados mentais depressivos, veja-se por exemplo o diagnóstico de Serenus fornecido por Séneca em De Tranquillitate Animi, 2, 6-15.

${ }^{14}$ Cf. e.g. Stanley W. Jackson, Melancholia and Depression. From Hippocratic Times to Modern Times (New Haven and London: Yale University Press, 1986), 1-12. 
depressão persistente aos intentos suicidas ${ }^{15}$.

Sabemos hoje que essa substância cuja existência fora indubitável para tantos autores é um mito que o curso da história foi tornando mais volumoso e intrincado, servindo de tela em que cada sociedade projectou alguns dos anseios possíveis de acolher sob os seus motivos maiores: a tristeza e o medo ${ }^{16}$. Não se julgue contudo que por mito se deve entender uma narrativa irreal. Trata-se sim de um mito operatório que serviu de base a exímios inquéritos tanto às causas empíricas de certos estados mentais como à eliminação ou alívio de seus sintomas mais intensos.

Aristóteles não se refere de modo sistemático ao que podemos considerar patologias mentais, contudo em sua obra zoológica, ética e psicológica é recorrente a abordagem de certas condições e disposições que afectam diferentes funções da alma (vegetativa, apetitiva e contemplativa) bem como a construção e manifestação do carácter. A concepção de doença [vóoos] remete tanto para um temperamento congénito como para o desequilíbrio nos humores, por forma a explicar certos comportamentos desviantes em relação à prossecução do bom individual e colectivo.

Além da indistinção entre várias perturbações, na Antiguidade é atribuída à doença uma origem eminentemente orgânica, mesmo quando as suas manifestações são exclusivamente mentais e comportamentais. É certo que se reconhecia a ideia de doenças da alma mas a sua abordagem e tratamento estão o mais das vezes circunscritos às escolas filosóficas que, como veremos de seguida, adoptaram analogias e metáforas entre os distúrbios mentais e as patologias ou disfunções do corpo. Podemos sustentar que, como nos diz Jackie Pigeaud: "são os médicos que fornecem o material coerente a definição de doença, mas o lugar de origem da analogia é a filosofia que experimentou tal necessidade por forma a descrever certos comportamentos do indivíduo"17.

15 Por exemplo, no segundo dos casos médicos relatados no terceiro dos livros Epidémicos são dados a ler os vários sintomas associados à bílis negra: "aversão à co-

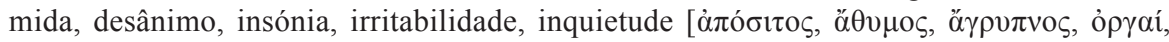

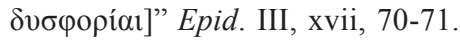

16 Apesar de ter perdido o estatuto de vocábulo técnico da psiquiatria médica, a melancolia pode ser identificada com o conjunto geral de sintomas associados ao termo depressão e respectivas variedades de diagnóstico apresentadas no Diagnostic and Statistical Manual of Mental Disorders. Mas além da rica tradição do conceito técnico trabalhado na Psicanálise, a melancolia sobrevive hoje sobretudo como termo vago utilizado na comunicação coloquial. Cf. Stanley W. Jackson, "A History of Melancholia and Depression" in History of Psychiatry and Medical Psychology. With an Epilogue on Psychiatry and the Mind-Body Relation, ed. Edwin R. Wallace e John Gach (New York: Springer, 2009), 443-460.

17 Jackie Pigeaud, La maladie de l'âme. Etude sur la relation de l'âme et du corps dans la tradition médico-philosophique antique (Paris: Les Belles Lettres, 1981), 15-16. 
Como veremos, o valor da analogia médica em Aristóteles tem dois grandes propósitos e valências éticas. Por um lado, ela remete para a importância da aplicação de princípios em casos concretos, aplicação que requer sempre uma certa capacidade de tradução. Por outro, está concentrada no valor do "justo meio" que à imagem das prescrições médicas se assume como central em matéria de comportamento ético ${ }^{18}$.

Mas importa sublinhar que ao recorrer à analogia e à metáfora para veicular e desenvolver temas éticos o pensamento filosófico não permanece necessariamente apartado da dimensão física da perturbação mental, nem mesmo da patologia.

É evidente que a medicina antiga não se escusa da abordagem de perturbações psíquicas, contudo considera que na "origem" de tais perturbações ou patologias ou pelo menos na sua base está uma desordem ou desequilíbrio orgânico. Assim, nos casos em que as fantasias ou as emoções são consideradas hipoteticamente como causas principais ou adjacentes da doença mental, ou mesmo quando a psicoterapia é considerada por forma a debelar ou atenuar as perturbações da mania e da melancolia, é no desequilíbrio humoral e no órgão base do juízo e da cognição (seja o coração, o cérebro ou mesmo o sangue) que os médicos se concentram. $\mathrm{O}$ maior conhecimento do corpo leva a uma evidente complexificação do conceito de "doença da alma". Contudo, a forte relação que as "comunidades científicas" estabeleceram entre a constituição física, os sintomas e mesmo a disposição moral (nos escritos fisiognomónicos), torna altamente improvável a concepção de doenças exclusivamente mentais no mundo antigo.

O fisicalismo daqueles primeiros autores vai ao ponto de, mesmo ao considerarem doenças resultantes em perturbações mentais, raramente procederem à divisão entre o corporal e o psíquico, considerando somente processos físicos e a investigação das causas materiais de tais perturbações que poderiam ter como manifestações a distorção da realidade indiciada no comportamento do indivíduo e/ou o seu próprio relato de dores e tormentos vários ${ }^{19}$.

18 Cf. Werner Jaeger, “Aristotle's Use of Medicine as Model of Method in His Ethics", The Journal of Hellenic Studies, 11 (1957), 54-61; "A medicina como Paideia", in Id., Paideia: A formação do homem grego, trad. Artur M. Pereira (Sao Paulo: Martins Fontes, 1986) 1029-1035.

19 Sobre a preponderância da investigação do físico como recurso imaginativo que tornava explicável o mental ver a perspectiva fornecida pela classicista Brooke Holmes no seu: The Symptom and the Subject. The emergence of the physical body in Ancient Greece (New Jersey: Princeton University Press, 2010), 121-191. Cf. tb. Bennett Simon, "Mind and Madness in Classical Antiquity" in History of Psychiatry and Medical Psychology. With an Epilogue on Psychiatry and the Mind-Body Relation, ed. Edwin R. Wallace e John Gach (New York: Springer, 2009), 175-198. 
Mas se estes médicos desconsideravam o alcance e a eficácia das palavras e dos argumentos filosóficos na cura de doenças mentais, isso não significa a existência de uma cisão absoluta entre o domínio da cura médi$\mathrm{ca}$, adstrito à causalidade física e somente comprometido com o assegurar da vida, e o florescimento da tradição das escolas helenistas que podemos designar, ainda que incorrendo num certo anacronismo, como cultoras de "tecnologias" psicoterapêuticas. Esta tradição que se começa a delinear no final do século $\mathrm{V}$ a.c., remonta às escolas platónica e aristotélica, pois aí se lançam as bases sistemáticas de um modo de viver em que o cuidado de si se torna uma disposição cujo aperfeiçoamento jamais cessa ao longo da existência individual. Aqui se encontra uma distinção fundamental, contraposta ao procedimento típico da medicina, a filosofia apresenta-se como terapia não de modo a resolver uma situação pontual ou um infortúnio, mas aproximando-se gradualmente da ideia de uma arte de vida. É nesse contexto que tem pertinência esclarecer os dois grandes sentidos da ideia de "doença da alma" que figura em diferentes textos filosóficos. Foi privilegiada a tradição que foi abraçada e transmitida por Pierre Hadot, aquela que aproxima diferentes escolas filosóficas de um modelo integral de vida, dispondo de uma variedade de recursos e aperfeiçoamento de si, sobretudo as variantes

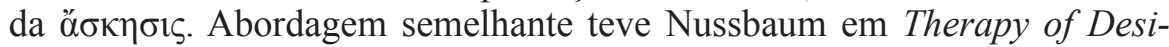
re ao mostrar a considerável frequência com que a metáfora médica esteve presente nos modelos de exame e terapia das paixões nas escolas helenistas, especialmente as de influência aristotélica. Foi esta defesa de uma diferenciação do "argumento terapêutico" nas escolas filosóficas da Grécia Clássica e do período helenista, que fundou a crítica de Nussbaum ao modo como na sua genealogia do "cuidado de si" Foucault teria indevidamente misturado a especificidade do empreendimento filosófico com os interesses de outros actores sociais. De acordo com a filósofa, as técnicas de si da filosofia se comprometem com a razão e não devem ser confundidas com práticas religiosas, políticas e médicas mais difusas.

Contudo, levada ao extremo, essa crítica pode implicar um indevido apagamento da incursão do pensamento filosófico nos debates da constituição física do homem e seus meios de tratamento, sendo neste âmbito que emerge uma tradição filosófica de observação e tratamento das "doenças da alma" que terá os estados melancólicos como objecto privilegiado. É possível defender que a filosofia médica foi além da metáfora médica como simples paralelismo entre o método das escolas filosóficas e os procedimentos médicos de incidência no corpo. 


\section{Génese da concepção aristotélica de melancolia nos textos hipo- cráticos}

Ainda que em grande parte do $\mathrm{CH}$ muitas das descrições semiológicas não surjam sob a aba de uma doença ou categorização maior, nele, em consonância com o que ocorrerá ao longo da antiguidade, as perturbações mentais foram frequentemente agrupadas em três grandes categorias: freni-

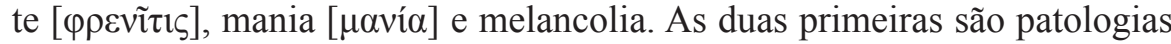
agudas. A frenite agrega perturbações súbitas altamente debilitantes acompanhadas de convulsões e febre como é o caso da meningite ou da epilepsia. A mania provoca desordem emocional e mental, formas de distorção da realidade por vezes acompanhadas de alucinações, e em certos casos de perturbação da identidade. Já a melancolia, mesmo nas suas formas mais graves, é indissociável do carácter do indivíduo, concentrando-se as suas manifestações no ânimo e na vitalidade psicofísica ${ }^{20}$. Ela foi frequentemente tomada como condição normal que só em certos casos deve ser objecto de atenção médica ${ }^{21}$. Contudo, no curso da sua nosografia e do seu retratamento literário, o melancólico aparece como sujeito a movimentos emocionais intensos que decorrem de uma conduta ética particular ou simplesmente de uma atribuição divina.

Tudo indica que o reconhecimento generalizado da existência desse humor é tardio ${ }^{22}$, prevalecendo em muitos dos textos hipocráticos o uso do termo bílis, que a par da flegma foi considerado a causa da maioria das perturbações. Parece ter sido na passagem para o século IV a.C. que, além do sangue, do flegma e da bílis (amarela) se adicionou um quarto humor cuja existência terá sido deduzida da coloração de excreções e do sangue mais negro, estando desde então associada à tez mais escura ${ }^{23}$. Esse humor é a

20 Ver por exemplo a obra de Hellmut Flashar, Melancholie und Melancholiker in der medizinischen Theorien der Antike (Berlin: de Gruyter, 1966), 21 e ss.

21 Jackson, "A History of Melancholia..." 443-444.

22 Isso mesmo parece claro em Da Natureza do Homem VII, onde a designação da bílis negra mostra que a sua existência não tem o mesmo grau de evidência da amarela, por exemplo aquando da discussão da prevalência dos distintos humores em cada uma das estações do ano: “(...) a bílis, primeiro a amarela, e depois a chamada [bílis] negra

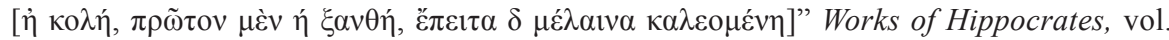
4, (London / Cambridge: William Heinemann / Harvard University Press, 1959), 22.

23 Muitas das descrições dos elementos da krasis e dos processos fisiológicos que acompanham determinados estados emocionais e mesmo o carácter individual, foram-se cristalizando em expressões coloquiais. Essa relação estreita entre a ocorrência física e os estados emocionais ou disposições remonta aos textos homéricos e ficou plasmada na tragédia. No $\mathrm{CH}$ assim como em textos de Aristóteles, encontramos não só as referências genéricas a um paralelismo entre o desequilíbrio humoral (ou térmico) e o cognitivo, mas 


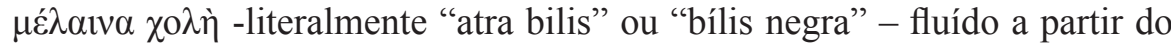
qual se deduz a referência à $\mu \varepsilon \lambda \alpha \gamma \chi 0 \lambda i ́ \alpha$ (melancolia) em textos onde não figura este termo, como é o caso em Da Natureza do Homem e no Problema

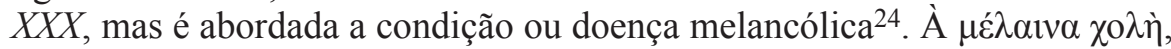
são atribuídas duas origens distintas, ou provém da segregação operada pelo fígado para auxiliar o processo de nutrição ou é proveniente da degradação ou combustão do sangue, resíduo que o corpo não consegue expelir. Em ambos os casos a sua prevalência é considerada contrária aos humores e condições saudáveis. Nos escritos hipocráticos esse humor frio e seco, diluído no sangue ou afectando directamente a sede do intelecto (o coração ou o cérebro) tem consequências danosas no estado emocional, tendo o autor do livro sexto dos Aforimos identificado os seus sinais: "medo e depressão pro-

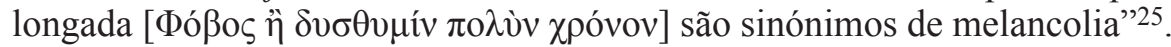
A desregulação emocional pode ter origem: no 1) desequilíbrio do balanço humoral numa constituição originalmente saudável, 2) no isolamento e predomínio da bílis negra tal como proposto em Da Natureza do Homem, ou ainda 3) no arrefecimento da bílis como se pode depreender da generalidade dos textos. Por outro lado, na medida em que além do temperamento inato, a melancolia pode ter como origem um desequilíbrio adquirido devido a certas circunstâncias ou hábitos, há um crescente reconhecimento da necessidade de medidas profiláticas e está difundida a ideia de que, uma vez contraída a patologia, a cura completa é impossível. Como veremos, a referência tanto ao carácter irreversível como à instabilidade inerente à condição melancólica estão bem presentes nos textos aristotélicos. Além da adaptação da dieta, o tratamento proposto pelos autores posteriores centrar-se-á em métodos purgativos diversos, com destaque para o uso do heléboro ${ }^{26}$ e, consoante a particularidade da condição melancólica, o exercício físico, a sangria e a abstinência. Já a admissão de factores mentais e sociais tanto na origem do desequilíbrio como no seu restabelecimento é tardia e gradual. Em consonância, é o equilíbrio relativo dos humores (incluindo aqui fluídos por vezes considerados distintos como o sangue e certos resíduos) que assegura a

\footnotetext{
também expressões que se fixaram na generalidade das línguas indo-europeias. Além de associações genéricas do sanguíneo com a vivacidade e estado saudável e o escuro com a doença e a morte, encontramos expressões idiomáticas que caracterizam os indivíduos por metonímia ou metáfora que procede de um putativo processo ou propriedade físicos, é esse o caso no "agir de cabeça quente" ou na contraposta "frieza de espírito". Além destas, temos oposições frequentes na formação da doutrina dos humores, que sempre manteve proximidade assinalável à culinária, entre o doce e o amargo.

24 Note-se que o termo $\mu \varepsilon \lambda \alpha \gamma \chi 0 \lambda i ́ \alpha$ está ausente do Corpus Aristotelicum.

25 Aph. VI, 23.

26 Nas variedades: Helleborus niger e Veratrum album.
} 
estabilidade mesma da designação do carácter individual. Contudo, tal designação, que individualiza tem por referentes o biológico, em particular a estação da vida em que o indivíduo se insere, e o atmosférico, pela sujeição às condições climáticas da estação do ano ${ }^{27}$.

As reticências quanto às incursões da medicina numa teoria geral da

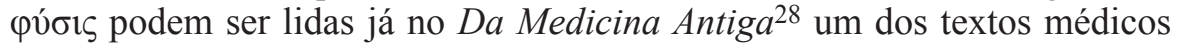
onde primeiro surge o termo $\varphi \imath \lambda$ oбo $\varphi \imath \alpha$, e manter-se-ão em diversos tratados que compõem o $\mathrm{CH}$. Essa posição deve ser interpretada como derivação de uma reação mais alargada das comunidades médicas relativamente à difusão e influência crescente da "medicina do templo" baseada em rituais catárticos. $\mathrm{O}$ autor daquele texto tem em vista concepções como a de Empédocles, e anteriormente do naturalismo jónico, que remetem para elementos naturais, entidades imutáveis constituintes do homem e cuja quebra da tensão dos contrários é considerada causadora de doenças. É assim que se rejeitam as hipóteses daqueles que investigam o que existe "no céu e sob a terra" [ $\tau \tilde{\omega} v$

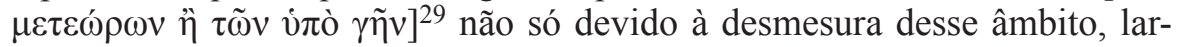
gamente indiferente à saúde dos homens, mas porque o mesmo, incidindo sobre aspectos inalcançáveis pela experiência não tem propriamente um método ou técnica próprios que lhes permita ir além de raciocínios rebuscados.

Já a diferenciação da medicina de acordo com o autor desse tratado decorre de um saber acumulado que remonta ao momento em que os homens se libertaram de uma dieta similar à dos animais, a qual seria consideravelmente danosa para a saúde. Esse saber requer não só a cozedura e confecção dos alimentos mas também a sua adaptação a constituições naturais particulares, facilitando para cada caso a assimilação dos alimentos benéficos. Essa centralidade do processo da cocção [ $\pi \varepsilon ́ \psi i \varsigma]$ é reveladora de uma perspectiva que não atribui prioridade à procura de uma essência, nem sequer à candente questão de saber qual a composição (ou unidade) do indivíduo, com que se ocupam outros autores do $\mathrm{CH}$, mas à sucessão interminável de relações (aquisição, troca, retenção e excreção) que se estabelecem entre o interior do organismo e o meio ${ }^{30}$. É estabelecido um paralelismo entre as potencialida-

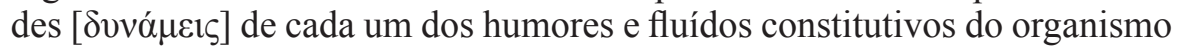

27 Só mais tarde serão adicionadas e sistematizadas as regências maiores e os encadeamentos astrológicos que influenciam sobre cada uma constituição natural, no caso do melancólico à distância fria do Kronos/Saturno, decaído da idade do ouro, cf. e.g. Raymond Klibansky et al., Saturn and Melancholy: Studies in the History of Natural Philosophy, Religion, and Art (Nendeln: Kraus, 1979 [1964]), 133-158.

28 Cf. Vet. Med. xx, 1 e ss.

29 Vet. Med. i, 23-24.

30 Cf. Vet. Med. xx. 


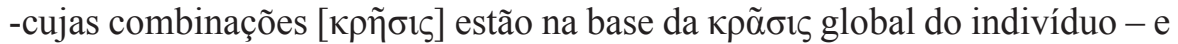
as qualidades, sobretudo o doce e o amargo, presentes nos próprios alimentos disponíveis no meio ${ }^{31}$. Por si só, o conhecimento obtido por via empírica

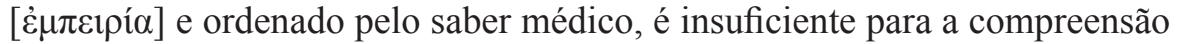
das alterações metabólicas subjacentes à degradação e promoção da saúde. A recusa da alopatia, método de cura pelos contrários que pode ser encontrada na maioria dos trabalhos hipocráticos, decorre da defesa de um mecanismo de reajustamento das qualidades da mistura interior a partir da potencialidade das qualidades dos alimentos que podem ser confecionados e administrados. Essa cura pelo semelhante exige adicionalmente o conhecimento da natureza do desequilíbrio por forma a intervir no momento certo.

Apesar de não mencionar ainda a bílis negra, e ser avesso à teoria dos contrários adaptada no Problema XXX, este tratado contém ideias importantes para compreender aspectos decisivos na teorização da doença e padecimento mental. Nele se descrevem vários humores e fluídos que, provido cada um de potencialidade específica, se combinam num equilíbrio global sempre provisório. Não só é essa simetria - que caracteriza a composição bem tem-

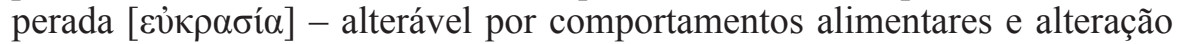
de hábitos, mas desde logo por força da degradação inevitável dos fluídos ao longo do tempo, uma transformação de que temos evidência na passagem do doce ao acre em diversos líquidos ${ }^{32}$.

A ideia de uma proporção relativa é central no modo como as ideias de meio-termo e de equilíbrio surgem nos primeiros escritos médicos do oci-

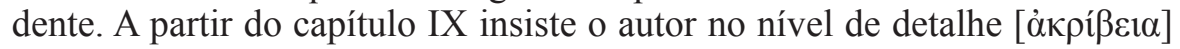
requerido para encontrar a justa medida $[\mu \varepsilon ́ \tau \rho o v]$ em cada caso, e o modo de ajustar o défice ou o excesso de um determinado humor, por recurso a alimentos que por vezes contém esse mesmo humor quase em estado puro. As respostas universais para o restabelecimento, como a dieta leve ou a abstinência podem ser benéficas na maioria dos casos, mas em muitos outros levarão ao enfraquecimento ou mesmo à morte ${ }^{33}$.

O tratado Da Medicina Antiga é neste ponto ilustrativo, na sua discussão dos danos causados pelo excesso e defeito (ou abstinência) na inges-

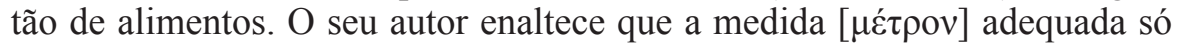
pode ser estabelecida com base na determinação da "sensibilidade corpórea"

31 Cf. Vet. Med. xiv.

32 Cf. Vet. Med. xxiv. O termo $\mu \varepsilon \tau \alpha \beta$ on í ocorre com frequência no $\mathrm{CH}$ designando o processo de mudança que passa ou pela metabolização de cada um dos elementos interiores, na origem da doença ou do restabelecimento. Em casos como em Da Natureza do Homem remete-se também para mudanças que têm lugar no mundo exterior, nomeadamente a sucessão cíclica das estações e das consequências climáticas e atmosféricas.

33 Cf. Vet. Med. viii-ix. 


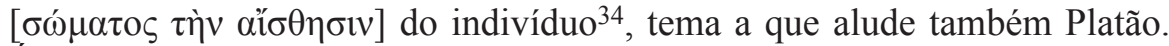
É aí que reside no seu essencial a concepção de eficácia desse saber e sua $\tau \varepsilon ́ \chi v \eta$, independentemente da boa aceitação do paciente de uma determinada prescrição, é necessária uma medida objectiva que fundamente a intervenção. A sensibilidade não se reduz ao gosto ou à avaliação "subjectiva" do doente, é ao médico que compete estabelecê-la, escapando a medicina ao relativismo de Protágoras plasmado na sua famosa máxima: “o homem é a medida de todas as coisas" 35 . O médico determina a sensibilidade do doente a certos elementos mas poderá também, quando isso for necessário para o seu restabelecimento, modificar os modos como essa sensibilidade é irritada. Um tema recorrente é o da dor ou, dito de modo mais expressivo, dos dissabores que podem estar implicados em tal reajustamento que previne males maiores. Defendia-se ainda no mesmo tratado que muitos dos danos decorrentes da inaptidão do médico para ler a medida individual só eram evidentes nas doenças mais graves ${ }^{36}$.

Neste tratado (e de modo mais desenvolvido em Da Natureza do Homem) se delineia uma distinção importante nas observações da melancolia que encontramos em Aristóteles e no Problema XXX. A manutenção do equilíbrio requer do paciente uma atitude proactiva, um zelo pelas regras básicas da higiene. Além de reforçar esse "cuidado de si", ao médico compete a observação e aferição tão objectiva quanto possível do equilíbrio individual e promover o seu restabelecimento. A intervenção no equilíbrio, dependente da proporção e estado dos humores, está centrada no corpo. Ela incide no seu $\pi$ oıะ̃̃v como função interior (do corpo) dependente das condicionantes dos humores presentes na constituição individual, e no seu $\pi \alpha \sigma \chi \varepsilon ı v$, função relativa ao conjunto de intervenções sobre o corpo a partir do seu exterior. Neste último, que remete para a sujeição do corpo a tudo que a partir do exterior

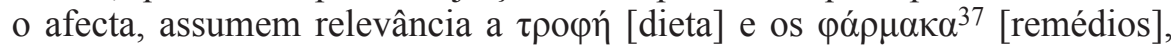
geralmente drogas purgativas fortes.

34 Vet. Med. ix, 18.

35 Ver a este propósito o paralelismo com a chamada "Apologia de Protágoras" incluída no Teeteto, onde Platão procura um critério que possa conferir objectividade da homo mensura, cf. Paul Demont, "About philosophy and humoural medicine", in Hippocrates in Context, ed. Philip J. van der Eijk (Leiden/Boston: Brill, 2005), 273-276.

36 Cf. Vet. Med. ix, 22-40; xxi.

37 O termo carrega ainda a designação de encantamentos mágicos e cânticos que podem acompanhar a administração de medicamentos. A analogia entre os poderes do pharmakon e os efeitos do discurso manter-se-á nos diálogos platónicos, tendo origem no Elogio de Helena de Górgias, cf. Pedro Laín Entralgo, The Therapy of the Word in Classical Antiquity, trans. L. J. Rather and J. M. Sharp (New Haven: Yale University Press, 1970 [1958]), 90-116. 
Semelhantes requisitos de compreensão da doença e procedimentos podem ser encontrados em Da Doença Sagrada, caso particular de um texto do $\mathrm{CH}$ dedicado inteiramente a uma doença que não deve ser considerada "mental" mas encefálica, a epilepsia, cujas causa e manifestação são iminente físicas. Além de negar a origem divina da perturbação, seu autor co-

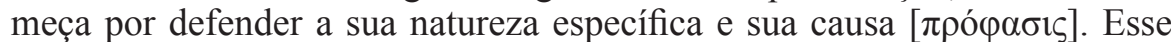
tratado permite-nos compreender aspectos da fisiologia peculiar dos antigos e o modo como a mesma é desvelada a partir de uma $\tau \dot{\chi} \chi v \eta$ distinta $^{38}$. Esta técnica decorre da conjugação entre uma teoria geral da especificidade da

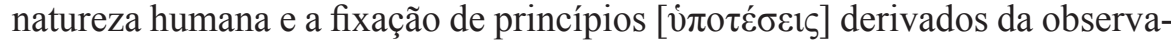
ção e experiência.

Segundo esse tratado, é ao cérebro que afluem os dados dos sentidos, através do ar [ợ́p], aí organizados em diferentes faculdades (visão e audição), é nele que se manifestam as emoções de prazer e dor ${ }^{39}$. Definido como

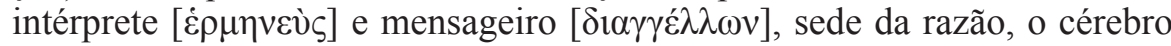
é afectado directamente não só pela flegma que obstrui a comunicação do ar $[\pi v \varepsilon \tilde{v} \mu \alpha]$ com os diferentes órgãos através dos vasos ou veias [ $\varphi \lambda \varepsilon \dot{\beta} \beta \alpha \varsigma]$, mas

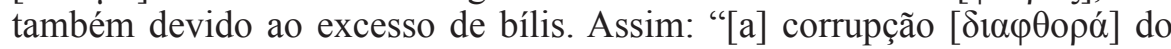

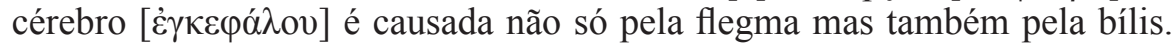
Podemos distingui-las da seguinte forma. Os que são loucos pela flegma são

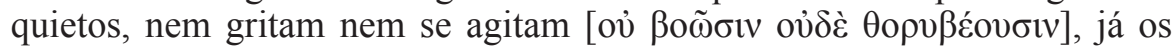
enlouquecidos pela bílis são barulhentos, malfeitores e inquietos, sempre fa-

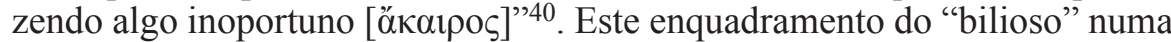
patologia que se expressa num determinado carácter será em grande medida

38 É assim que também neste tratado podemos encontrar a preocupação em diferenciar a prática médica de outros tipos de terapias disponíveis no mesmo período, cf. Morb. Sacr. II, 4-5. Eram diversas as práticas concorrentes da medicina praticada em Cós e Cnido. Entre as legítimas e aquelas que o autor unifica sob o intento comum de mascarar a ignorância com superstições, podemos mencionar um exemplo de origem popular, que os autores hipocráticos tomam como ancilares, o conjunto de actividades de assistência e alívio fornecidos pelas parteiras [ $\left.\mu \alpha \varepsilon \varepsilon_{i} \alpha\right]$. Outras resultam de conhecimentos milenares acumulados. É o caso da cura, baseada no conhecimento dos efeitos das raízes, fornecida

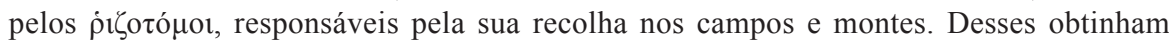
os $\varphi \propto \rho \mu \alpha \chi о \tilde{\omega} \lambda \alpha 1$ os conhecimentos práticos que lhes permitiam uma tarefa preservada nas civilizações posteriores, comercializar junto de praticantes e público indiferenciado os benefícios de um determinado espécime ou produto, cf. Geoffrey E. R. Lloyd, Demystifying mentalities (Cambridge: Cambridge University Press, 1990), 30 e ss. Além dos mencionados, há ainda tratamentos e rituais diversos com dimensão terapêutica de tipo taumatúrgico, oferecidos por uma miríade onde encontramos desde magos [ $\mu \alpha ́$ yor],

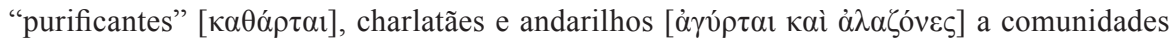
religiosas, cf. Lloyd, Demystifying mentalities, 50-72.

39 Cf. Morb. Sacr. XIX.

40 Morb. Sacr. XVIII. 
seguido por Aristóteles. Mas, como veremos, as ideias de sobrexcitação e de um desacordo com as circunstâncias e com as exigências do momento, sobretudo expresso pelo uso do termo ö́kaıрos, que remete para o extemporâneo, são em Aristóteles associados à doença melancólica mas somente num dos seus extremos. Ele remete para o desequilíbrio transitório da quantidade ou qualidade da bílis negra, que nesse caso tende, por via do aquecimento, para a sobrexcitação sempre próxima da loucura. Já no caso do melancólico por temperamento (ou compleição) natural se verifica uma maior estabilidade das manifestações.

Já o Da Doença Sagrada defende por sua vez, na secção XVIII, que a bílis que acorre ao cérebro, ainda indiferenciada como amarela ou negra, provoca o seu aquecimento, potencialidade inversa à flegma que o pode subitamente arrefecer aquele órgão provocando danos ao nível da memória ${ }^{41}$.

De acordo com o modelo agora exposto, as convulsões que caracterizam a epilepsia são tomadas como resultantes de uma obstrução da circulação do ar no organismo. Pelo excesso de flegma produzem-se obstruções que levam a que o ar fique retido nos órgãos neles exercendo pressão (provocando o movimento descoordenado) e o cérebro privado daquele mesmo ar fica impedido nas suas funções de coordenação dos sentidos. A humidade excessiva é considerada origem da indistinção que caracteriza a loucura ${ }^{42}$. O restabelecimento da humidade e do calor por via da dieta, aqui segundo o método alopático do reequilíbrio pelos contrários -do seco pelos alimentos que têm uma potencialidade metabólica de humedecer e do frio pelo que tem a potencialidade de aquecer o organismo-, é o modelo de terapia dominante: "quem

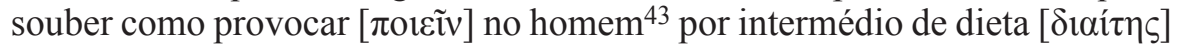
o molhado ou seco, o quente ou o frio, pode curar também esta doença, se distinguir as estações para o tratamento eficaz, sem recorrer a magia ou a purificações" ${ }^{4}$. Noutros tratados, a humidade é igualmente associada à lentidão e ao torpor da alma ( $\Psi v \chi \eta ́)$, ao passo que o calor está na origem de um excesso de velocidade na cognição, a qual é origem de sintomas maníacos ${ }^{45}$.

41 Esta mesma oposição entre a potencialidade da flegma e da bílis pode ser lida ao logo do tratado Dos Ares, Águas e Lugares.

42 Cf. Morb. Sacr. xiv.

43 De notar que na maioria dos MSS gregos esta última frase do tratado tem neste ponto

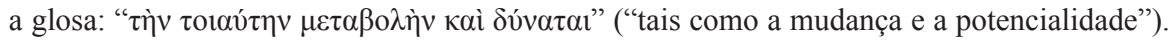

44 Morb. Sacr. xxi, 21-26.

45 Ver por exemplo o modo como em Do Regime se propõe a conjugação do fogo e da água num estado de equilíbrio em co-dependência, o qual é quebrado quando o fogo tende para o seco e a água para o húmido. No primeiro caso o processamento dos dados sensórios é veloz e provoca uma descompensação no contacto com o sensível, no segundo a transmissão pode ser veloz mas o processamento é retardado pelos humores húmidos, cf. Reg. i, 35 . 
Assim, se A Doença Sagrada, arauto da explicação médica liberta de factores religiosos ${ }^{46}$, admite elementos primários como causa natural da doença, ao invés de a atribuir a punições lançadas pelos deuses sobre os homens transgressores, não o faz de modo arbitrário. A mais recorrente crítica às abordagens dos filósofos naturais aponta para a sua tendência para a redução indevida das causas da doença, a par da desconsideração das hipóteses erigidas a partir da observação empírica.

Tais exigências de precisão fundamentam em Da Natureza do Homem o erigir de um verdadeiro sistema capaz de estabelecer uma correlação entre a compleição individual, a idade do homem e os ciclos da natureza. Aí, além da crítica a filósofos e oradores com que se inicia o tratado atribuído a Pólibo, no segundo capítulo é a vez de as perspectivas dos médicos (iๆ serem sujeitas a inquérito. Sob ataque estão aqueles que defendem que o ser humano é constituído por uma única substância, concepção que teria sido reforçada pela reacção dos diferentes organismos aos fortes purgantes e eméticos aplicados a pacientes que responderiam com a expulsão de uma substância específica ${ }^{47}$. Tal concepção contraria a ideia de "composição" e "mistura" na origem do indivíduo subjacente à maioria dos textos do $\mathrm{CH}$, ideia que aqui encontramos numa fase de desenvolvimento avançado coincidente com a defesa da tétrade humoral e sua conjugação com aspectos dietéticos, o ciclo das estações e a sequência das idades do homem. Já os que apregoavam um dos elementos naturais ou orgânicos (sangue, a flegma ou a bílis) como constituintes, faziam-no com recurso à forma específica da me-

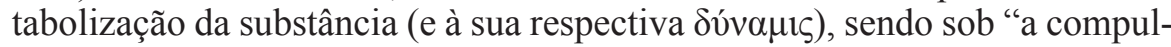

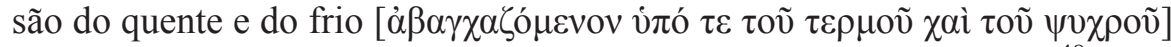
que a mesma se torna doce, amarga, branca, negra e por aí diante" 48 . Este recurso ao eixo da temperatura (quente-frio), mas também ao da humidade (molhado-seco), qualidades congénitas providas de potência e necessidade na modulação dos elementos é criticado naquelas doutrinas que supunham um monismo substancial. Mas é importante notar que ele é adoptado pelo próprio autor depois de discriminados no quarto capítulo os humores constituintes dos indivíduos. Exposto de forma elegante, esse esquema humoral tantas vezes reproduzido, permite antecipar a evolução de cada desequilíbrio e doença. "O corpo do homem tem em si sangue, flegma, bílis amarela e bílis negra; estes compõem a natureza de seu corpo e através deles ele sente dor ou goza de saúde [ن̛yıáveı]. Ele goza da maior saúde quando estes elementos

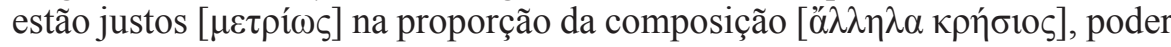

\footnotetext{
46 Cf Eijk, Medicine and Philosophy, 19-21.

47 Cf. Nat. Hom. vi, 1-12.

48 Nat. Hom. ii, 8-9.
} 
e massa entre si, perfeitamente misturados" 49 . É o equilíbrio e distribuição proporcional entre tais elementos no sangue e em cada um dos órgãos que determina a ausência de patologia e dor ${ }^{50}$. No indivíduo saudável, o sangue, a flegma, a bílis amarela e a bílis negra estão presentes em quantidades proporcionais e bem distribuídos pelos diferentes órgãos e partes do corpo. É a alteração da quantidade relativa de cada um dos humores, a sua degradação ou a separação de um face aos demais, que está na origem da doença e do sofrimento. De acordo com Da Natureza do Homem, tais alterações na constituição natural podem dever-se a erros no regime ou à qualidade do ar presente na atmosfera ${ }^{51}$. Neste ponto o texto é claro ao admitir que entre o equilíbrio óptimo e a doença são possíveis estados intermédios.

Contudo, a importância da qualidade da temperatura e da humidade na determinação da combinação dos humores, mesmo se por intermédio da influência das estações ou da atmosfera, pode ser maior do que se admitiria à partida $^{52}$. É importante reter este aspecto pois as concepções fisiológicas de Aristóteles e sobretudo a teoria exposta no Problema XXX estão apoiadas precisamente na primazia da oscilação da temperatura como variável primeira do estado psíquico.

Esta concepção materialista não significa que os primeiros escritos médicos incidam exclusivamente na patologia física, sem atender ao padecimento $\operatorname{associado}^{53}$. Uma parte significativa das doenças ou das perturbações descritas são compreensíveis somente numa linha contínua que conduz do físico ao

49 Nat. Hom. ix, 1-6.

50 Como assinalava William H.S. Jones, pela forma polida e articulada como apresenta os humores, o Da Natureza do Homem "é o único trabalho hipocrático que merece ser

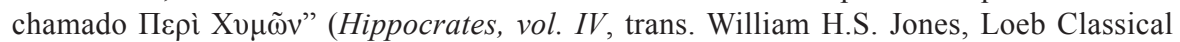
Library (London / Cambridge: William Heinemann / Harvard University Press, 1959), xxxii).

51 Cf. Nat. Hom. ix, 11-12.

52 Tese subscrita pelo papiro Anonymi londinensis, ex Aristotelis Iatricis Menoniis, composição hoje atribuída a um peripatético do primeiro século da era cristã. Numa argumentação inspirada pela abordagem hipocrática, esse texto atribuía ao quente e ao frio importância capital na manutenção da saúde do organismo, defendendo tratar-se de "qualidades misturadas de modo equilibrado" (cap. XIX, 6).

53 Nesta distinção entre patologia e padecimento procuro adaptar a distinção frequente na literatura médica anglo-saxónica entre "disease", que concerne a um tipo de anomalia (anatómica, bioquímica ou psicológica) e "illness" referente ao conjunto de sintomas associados experienciados pelo doente. Veja-se a este respeito a proposta de William E. Stempsey para o reconhecimento da interdependência de tais factores no âmbito da patologia clínica, plasmada na tese de que: "os valores jogam um papel crucial e fundacional no delinear do que tomamos como facto objectivo, Id. Disease and Diagnosis. Valuedependent Realism (New York: Kluwer, 2002), 2. Cf. Ibid., 117-118, 122-123. 
psíquico. Mas a verdade é que só com Galeno se estabelecerá um tratamento sistemático do modo como a compleição natural afecta o estado mental e o caracter ${ }^{54}$. No $\mathrm{CH}$ é descrita, a par com outras constituições, a fisiologia do melancólico, aquele cuja constituição inata é abundante em bílis negra, o mais viscoso dos humores caracterizado pelas qualidades do frio e seco agravadas no Outono e no ocaso da meia-idade ${ }^{55}$. É por associação e contraposição que se extraí da fisiologia um "temperamento" propriamente dito, sendo que esta condição e também o desequilíbrio temporário (doença) pode ser entendida como uma depressão da vitalidade iniciada com o declínio do sanguíneo, condição associada ao vigor e saúde.

O capítulo XIII de Da Natureza do Homem introduz a ideia de que a promoção da saúde se deve iniciar com o próprio paciente. Dele é esperado não só que leve uma vida regrada tomando precauções, mas que actue nas causas da doença de modo proactivo ${ }^{56}$. O médico está incumbido não só de inquirir quanto à particularidade da constituição individual e suas circunstâncias, mas em função de tais factores orientar o paciente. Independente da terapia propriamente dita, o mecanismo aqui presente funciona de modo recursivo, sendo necessário ao paciente ganhar periodicamente conhecimento do seu próprio estado e ajustar o seu regime.

\section{Platão e as variantes da loucura}

Além de prezar o método de conhecimento da natureza humana estabelecido por Hipócrates ${ }^{57}$ e de enaltecer o contributo dos médicos para a coesão social ${ }^{58}$, Platão forneceu uma interpretação da origem e significado das perturbações mentais e da loucura que, apesar de não incidir na melancolia, é relevante para entender a génese da aproximação filosófica ao problema do génio. A abordagem filosófica à doença ou disfunção mental do mundo antigo não se demarca da ideia da sua origem e estatuto fisiológico, mas remete para certos factores emocionais e mentais tanto na sua etiologia como terapia. Tais factores eram frequentemente atribuídos a falhas ou degradação moral, nomeadamente na gestão dos prazeres, aqui incluindo excessos alimentares, e à devoção religiosa exacerbada.

$\mathrm{Na}$ obra platónica é legível uma gradação entre as manifestações mais comuns da mania, nomeadamente a paixão incontrolável e as acções imorais,

\footnotetext{
${ }^{54}$ Cf. Flashar, Melancholie und Melancholiker, 24 e ss.

55 Cf. Nat. Hom. vii.

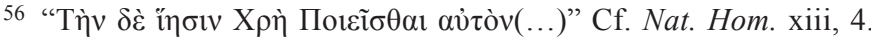

57 Cf. Platão Phdr. 270c. Ver tb. Platão, Symp. 186c e ss.

58 Cf. e.g. Platão, Politicus 308e.
} 
e as suas formas mais danosas e patológicas: as alucinações e perturbação da identidade. No Filebo, os sonhos caracterizados pela irrupção de instintos das partes inferiores da alma afectando a capacidade judicativa da alma ra-

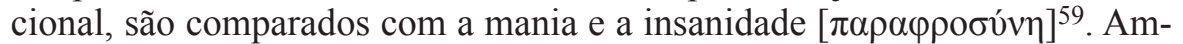
bos se posicionam para Platão ao nível das percepções e prazeres falsos que em última análise decorrem da "ancoragem" da alma racional nas suas partes mortais e tendem a afectar aqueles que levam uma vida marcada pelo excesso [úßpıs] que permite aceder aos extremos da dor e do prazer corpóreos ${ }^{60}$.

Dividiu Platão entre a parte "anímica" $(\theta v \mu o ́ s)^{61}$, localizada na zona cardíaca e responsável pela coragem e ira, e a parte apetitiva ( $\left.\dot{\varepsilon} \pi \imath v \mu \mu^{\prime} \alpha\right)$, situada abaixo do diafragma e fonte de necessidades vitais mas também de inclinações sensíveis inconciliáveis com a razão ${ }^{62}$. Se a primeira, também por sua proximidade à cabeça, pode, se bem dirigida, corresponder aos anseios e fins estabelecidos racionalmente, a segunda é por vezes obstinada na busca do prazer. É portanto desta última que as perturbações maníacas parecem $\operatorname{brotar}^{63}$.

No Fedro reconhecem-se duas origens da mania: "uma surgindo das do-

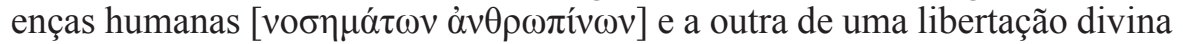

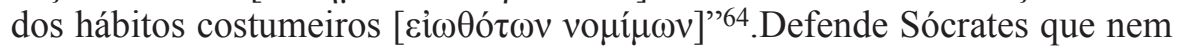
toda a loucura é danosa e como tal lastimável, aduzindo exemplos que mostram o modo como a mesma, caracterizada como divina, é propícia à transcendência em actividades particulares: nas profecias de Apólo, nos rituais de

59 Cf. Platão, Phileb. 36e.

60 Cf. Phileb. $45 \mathrm{~d}$.

61 Atendendo ao modo como no $\theta u \mu$ ó $\varsigma$ se mobilizam paixões e volições marcadas pelo ânimo, optamos por traduzir assim esta noção (que assumirá um papel central na psicologia aristotélica e em vários autores peripatéticos), em detrimento de "espiritiva" ou "irascível". Na base desta escolha está a adaptação do termo por parte de Séneca, que de modo parcialmente equívoco, o traduziu por "ira" indo além da ideia de loucura passageira, entrevendo uma ampla variedade de sentidos no horizonte semântico da virtus, cf. Seneca, De Ira I, 6. Séneca seguia Cícero que, nas Tusculanae Disputationes (IV, 9),

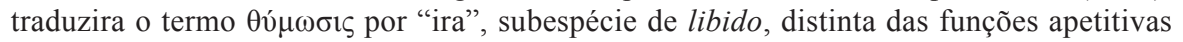
e de emoções afins como ódio, aversão e discórdia. Cícero complementou essa análise com a descrição do processo fisiológico de degradação do sangue e correlativa abundância de bílis e flegma.

62 As partes da alma com assento corpóreo são apresentadas no Timeu, cf. Ti. 69c $-71 b$.

63 Deve notar-se que esta divisão das funções da alma e sua disposição corpórea obsta a uma compreensão do dinamismo das disposições da alma, problema a que a tradição terapêutica das escolas helenistas, desde logo Crisipo, irá fornecer resposta, concebendo

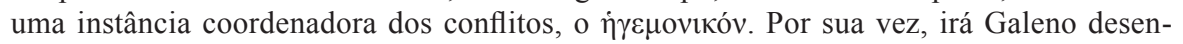
volver criticamente esse conceito estóico no âmbito da teoria da cognição.

64 Phdr. 265a. 
Dionísio, na poesia das Musas e no amor erótico de Afrodite ${ }^{65}$. Esta distinção entre as formas de loucura de origem divina e aquelas circunscritas a uma origem nosológica é fundamental. Essa contraposição da compreensão sagrada e profana da patologia tem um duplo condão. Manifesta a difusão das concepções hipocráticas da doença mental, ao mesmo tempo que resgata a abordagem da loucura do discurso médico -que em sua etiologia, diagnóstico e terapia se atém à sua dimensão física- e da depuração que o mesmo efectua dos elementos religiosos ${ }^{66}$. Por outro lado, aquela consideração das formas de loucura divina contrabalança a atitude generalizada da civilização grega relativamente às perturbações mentais, caracterizada pela sua estigmatização e exclusão sistemática dos seus portadores ${ }^{67}$. E este é um aspecto adicional em que o diálogo platónico se revela percussor da teoria presente no Problema XXX, apresentando uma forma genérica de loucura benéfica, a divina, contraposta a formas humanas danosas com origem eminentemente física ${ }^{68}$. Um importante aspecto deve ser destacado, as formas de loucura divina decorrem de uma inspiração superior, geralmente suscitada por uma contemplação do sensível. A beleza sensível é a ocasião para a alma se libertar dos grilhões das paixões terrenas. Mas como transparece no Ion e no $F e d r o$, sobretudo nas profecias e na poesia o $̇ v \theta o v \sigma ı \alpha \sigma \mu o ́ c$, tende a acometer as mentes mais simples ${ }^{69}$. Além da raiz etimológica que remete para o estar tomado de Deus, há ainda o sentido de furor referente a um estado de agitação motora. A este respeito parecem evidentes o cepticismo e a ironia de Sócrates quanto à consideração de quaisquer dons divinos.

No Timeu toda a falha da alma é entendida como estando dependente da constituição e mistura corpórea dos humores, identificados com os quatro elementos constitutivos da natureza: ar, água, fogo e terra ${ }^{70}$. Ao distinguir os dois tipos de óvora, isto é, doenças impeditivas do uso da faculdade racional,

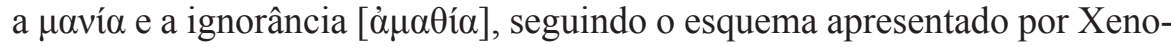

65 Cf. Phdr. 265b.

66 Não que as referências aos deuses estejam ausentes dos escritos médicos, mas as mesmas perdem o caracter operatório tanto na identificação das perturbações físicas ou psíquicas, como nos métodos de cura adoptados.

67 Cf. Kathryn A. Morgan, "Inspiration, recollection, and mimesis in Plato's Phaedrus" in Ancient Models of Mind. Studies in Human and Divine Rationality, eds. Andrea Nightingale and David Sedley, (New York: Cambridge University Press, 2010), 45-63.

68 Cf. Phdr. 244a e ss. Cf. Hellmut Flashar, Melancholie und Melancholiker, 62.

69 O mesmo se pode depreender das afirmações de Sócrates em pontos-chave de cada um dos diálogos, cf. Phdr. 244b; Ion 534. Sobre o entusiasmo como estado essencial da passagem ao extraordinário na religião grega, Cf. Walter Burkert, Griechische Religion der archaischen und klassischen Epoche. 2. überarbeitete und erweiterte Afl. (Stuttgart: W. Kohlhammer, 2011), 172-184.

70 Cf. Ti. 86a e ss. 
fonte nos Memorabilia ${ }^{71}$, Timeu defende que elas resultam ou da incorrecta constituição do corpo ou de uma dieta desadequada ${ }^{72}$. Esse desequilíbrio dos humores afecta as três partes da alma e a sua relação "simétrica" provocando nas mesmas distintas disfunções. Os casos mais graves nas doenças da alma, considera Timeu são aqueles em que as perturbações decorrem de excessos de prazer ou dor, os quais, de tão extremos, mantém o raciocínio absolutamente cativo na sua procura ou na saída da perturbação ${ }^{73}$. No caso da mania o indivíduo padece de um predomínio da parte apetitiva sobre a racional, ao passo que na ignorância estamos perante um desequilíbrio impeditivo da capacidade de memorizar e julgar. Assim se reconhece ao desequilíbrio não só uma origem corpórea, mas também espiritual, ainda que em ambos os casos o suporte físico do corpo seja o local de incidência. Para restabelecer o equilíbrio propõe Timeu o reajustar da prevalência do corpo ou da alma consoante num indivíduo uma daquelas esteja mais exercitada ou desenvolvida ${ }^{74}$. Só em casos extremos recomenda a purificação com recurso a fármacos ${ }^{75}$, defendendo o exercício activo do indivíduo, tanto na ginástica como na instrução. Mas como método de autoconhecimento das próprias debilidades recomenda a contemplação meditativa como via privilegiada de acesso e "reconciliação" com a sua a sua própria constituição (corpórea) originária, a qual radica na essência da alma já presente no momento da própria concepção ${ }^{76}$.

É de acordo com essa ideia de uma disposição natural predeterminada, nomeadamente quanto ao domínio de uma das partes da alma sobre as demais, que tanto na República como nas Leis pode Platão avançar com uma proposta de sociedade baseada numa clara e rígida divisão do trabalho. Por outro lado, numa sociedade em que os elementos e comportamentos tidos por nocivos são objecto de interdição, independentemente da atracção que exercem sobre os indivíduos, uma das fontes principais de desregulação conducente às patologias é logo à partida (idealmente) suprimida. Daí a prioridade atribuída à constituição e à orgânica da cidade, nomeadamente ao modo

${ }^{71}$ Cf. Ti. 86 b. Refere Xenofonte que, contrariamente ao que fora sustentado no libelo condenatório de Sócrates, para o filósofo o maníaco deve ser encarcerado, pois constitui ameaça à ordem pública, ao passo que o ignorante merece ser educado, cf. Mem. I. II. 49-50.

72 Cf. Ti. 89 c.

73 “(...) pois quando um homem está deleitado ou, inversamente, sofrendo de dor, ele está tão envolvido na aquisição de um ou no termo do outro, que lhe é impossível ver

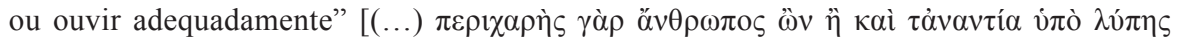

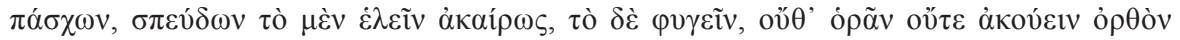

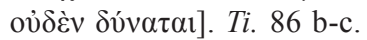

74 Cf. Ti. 88 a-c.

75 Cf. Ti. 89 b.

76 Cf. Ti. 90. 
como nela se promove a paideia. Esse modelo normativo rígido de saúde que privilegia a pureza será atenuado por Aristóteles. Mantendo uma visão normativa da saúde, Aristóteles prescinde de um modelo político capaz de erradicar a doença, descrevendo-a como desvio inerente à condição física, psíquica e social do humano.

\section{A fisiologia da sensibilidade melancólica nos escritos naturais de Aristóteles}

É certo que ao privilegiar a investigação da dimensão física do homem, integrando-o no cosmos, Aristóteles seguia a tradição hipocrática e boa parte do pensamento filosófico precedente, de demarcação face às explicações sobrenaturais dominantes em civilizações limítrofes. Contudo, isso não significa que abdique de uma ordenação de tipo religioso subjacente à percepção, explicação e intervenção nos processos naturais, algo que tem a sua expressão maior na prevalência da concepção teleológica que serve de base ao conceito de Physis ${ }^{77}$.

Diógenes Laércio deu-nos conta da intenção do filósofo de Estagira em redigir um tratado, composto por dois livros intitulado 'I $\alpha \tau \imath \kappa \alpha ́$ (Acerca da Medicina) que, a ter sido escrito, parece não ter sobrevivido ${ }^{78}$. Na sua obra conhecida e cuja autoria está a salvo de disputa, Aristóteles destaca as afini-

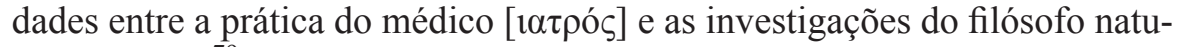
ral $[\varphi v \sigma i \kappa o ́ s]]^{79}$. Contudo, reconhece a ambas propósitos distintos. Enquanto para o médico o conhecimento da $\varphi v ́ \sigma ı \varsigma$, mesmo sendo integral ${ }^{80}$, visa uma gestão ou aplicação terapêutica ao humano, o conhecimento teórico da na-

77 Cf. Bernd Steinebrunner, Die Entzauberung der Krankheit. Vom Theos zum Anthropos - Über die alteuropäische Genesis moderner Medizin nach der Systemtheorie Niklas Luhmanns (Frankfurt a.M.: Peter Lang, 1987), 183-203.

78 Cf. Diog. Laer. V, 25.

79 Em Da Sensação e do Sensível afirmava Aristóteles: "Ao filósofo natural compete inquirir quanto aos primeiros princípios da saúde e da doença. Pois nem a saúde nem a doença têm lugar nos animais privados de vida. Assim, aqueles que estudam a natureza acabam por lidar com a medicina, enquanto que os médicos que exercem sua arte [ $\tau \dot{\varepsilon} \chi v \eta]$ de um modo mais filosófico consideram os princípios médicos a partir da natureza." $D e$ Sensu 436 a 17 - b 1.

${ }^{80}$ Isto é, de acordo com a resposta seleccionada para a velha questão, com que Platão se debateu, saber qual o âmbito de conhecimento requerido para compreender o ser humano? Cf. Phdr. 270c. Para o debate dessa interrogação continua pertinente a leitura de Fritz Steckerl acerca da continuidade entre a interpretação que fez Platão de textos, ideias e teorias hipocráticas e o enigmático papiro Anonymi londinensis, cf. Id. "Plato, Hippocrates, and the 'Menon papyrus'”, Classical Philology, 40 (1945), 166-180. 


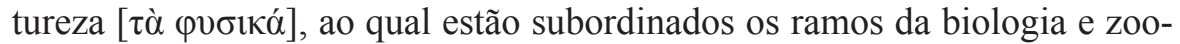
logia ${ }^{81}$, implica uma investigação empírica do mundo físico que deve fazer parte da formação do homem culto. Como sublinhou Jaeger, nos seus escritos sobre física natural Aristóteles parte de uma distinção entre o praticante de uma determinada ciência e o conhecimento do homem culto, cisão que no caso da medicina implica que o conhecimento da doença está sob escrutínio dos teóricos, de acordo com a ideia de que a "especialização excessiva" $(\grave{\alpha} \kappa \rho ı \varepsilon \varepsilon \iota)$ não deve ocupar o homem livre ${ }^{82}$.

Aristóteles aborda a doença de modo transversal como ocorrência que afecta a simetria entre os opostos, tanto entre o leve e o pesado como entre o quente e o frio, interferência danosa no estado de vida ideal das diferentes espécies ${ }^{83}$. Mesmo se congruente e elucidativa de práticas médicas, essa abordagem é estritamente teórica. Assim, apesar de deixar implícita a crítica a uma arregimentação excessiva dos praticantes de cada saber, Aristóteles parece ciente da razoabilidade das reservas dos autores do $\mathrm{CH}$ com respeito à especulação filosófica e à sua recorrente tentativa de reduzir as causas das doenças a um punhado de hipóteses ou princípios, contrapondo que as causas de uma mesma doença assim como suas manifestações podem ser diversas, de acordo como a especificidade do indivíduo, sua constituição e circunstâncias.

A abordagem de Aristóteles, por via do seu conhecimento prévio das temáticas médicas e pela sua entrada na Academia ainda em jovem, não foi indiferente às incursões platónicas no domínio médico, em especial às suas considerações relativas à mania e à relação entre doença mental e dons "supra-racionais". À imagem de Platão, que em certos pontos se revelou conhecedor e adepto da teoria dos humores, a sua abordagem das doenças mentais centra-se na base fisiológica dos estados mentais. Mas Aristóteles fá-lo com maior incidência nos processos materiais subjacentes aos apetites e às paixões e mantendo reservas e divergências relativamente à difundida doutrina dos humores ${ }^{84}$. A esse respeito são notórias as diferenças ao nível dos elementos fundamentais que constituem o corpo, revelando-se Aristó-

81 Cf. Part. An. 639a. Ver a propósito das mutações do modelo triádico de divisão da filosofia antiga o texto clássico de Pierre Hadot: "Les divisions des parties de la philosophie dans l'Antiquité", Museum Helveticum, 36 (1979), 201-223.

82 Cf. Werner Jaeger, "A medicina como Paideia" 1017-1020. Cf. e.g. Aristotles, Pol., VIII, 2, 1337 b 15.

83 Cf. Geoffrey E. R. Lloyd, In the Grip of Disease. Studies in the Greek Imagination (Oxford: Oxford University Press, 2003), 178-179.

${ }^{84}$ Como mostrou Paul Demont, a subscrição das teses hipocráticas por Platão é em certos casos claramente céptica quanto à especificidade das combinações e manifestações

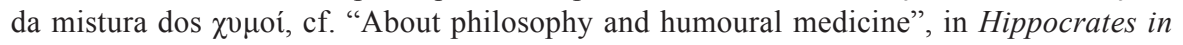
Context, ed. Philip J. van der Eijk (Leiden/Boston: Brill, 2005), 276-278. 
teles influenciado pela tétrade dos elementos primeiros com proveniência em Empédocles e na escola siciliana, e pela concepção cardiocêntrica do intelecto ${ }^{85}$. Na verdade, será mais correcto falar numa adaptação da teoria de Empédocles, pois Aristóteles não só crítica a imutabilidade dos elementos naturais de base (fogo, ar, terra, água) ${ }^{86}$ como os complexifica, formulando novas qualidades e uma teoria dos contrários que oferece mais possibilidade de combinação ${ }^{87}$. Essa perspectiva está sustentada no livro I da Físi$c a$ onde os objectos são apresentados como compostos da substância que mudam consoante a dinâmica formal dos referidos contrários (fogo, ar, terra, água). Deve contudo notar-se que aquilo que muda não são os opostos que actuam sobre a substância, mas os elementos no seu devir imanente. O movimento e a mudança para um novo composto só é possível pela privação a que a forma dá resposta. Mas em termos materiais essa mutação tem de ser concordante com requisitos de contiguidade, nomeadamente da partilha de uma das qualidades que caracterizam cada um dos contrários (quente-frio; seco-húmido) como será exposto no segundo livro do $D a$ Geração e Corrupção ${ }^{88}$. Assim, um elemento de fogo - quente e seco - não pode transformar-se em água - frio e húmido - pois não partilham qualidades; já a passagem do ar - quente e húmido - à água é possível por via da eliminação da qualidade "quente" superada pelo frio.

A referida influência da escola siciliana estender-se-á também ao nível terminológico como é legível na preferência do termo v̉ypov [fluído] em detrimento de $\chi v \mu$ ós. Mas o que é prioritário destacar na sua abordagem é o modo como toda a sua abordagem da fisiologia humana se centra nos pode-

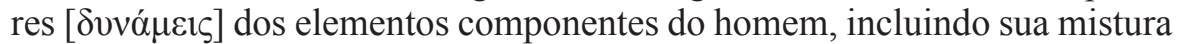
e factores subjacentes à sua variação. A par desses elementos constituintes,

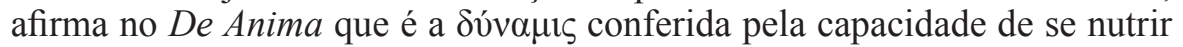
que, como a capacidade do tacto, distingue o vivente do inanimado ${ }^{89}$. A actualização dessa potencialidade bem como os seus modos passivo e activo, estão sempre dependentes das formas específicas dos indivíduos (e sua es-

85 Cf. James Longrigg, Greek Rational Medicine: Philosophy and Medicine from Alcmaeon to the Alexandrians (New York: Routledge, 1993), 104 e ss.

86 Veja-se a análise de Timothy J. Crowley ao uso, que alguns consideraram depre-

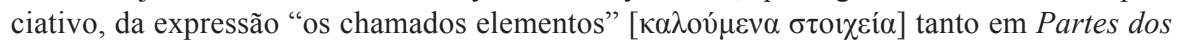
Animais como na Metafísica: Id., Aristotle's 'So-Called Elements, Phronesis 53 (2008), 223-242. Contudo, para Aristóteles era inequívoco o avanço teórico envolvido no abandono tanto dos princípios únicos como dos múltiplos que caracterizavam as cosmogonias jónicas. Tal abandono tem lugar com a fixação, por parte de Empédocles, de um conjunto limitado de princípios, cf. Phys. I, 6, 189a $12-20$.

87 Cf. Longrigg, Greek Rational Medicine, 149-176.

88 Cf. Aristóteles, De gen. et corr. $329 \mathrm{~b}$ e ss.

89 Cf. Aristóteles, De An. II, 2, 413a 24 e ss. 
pécie), nomeadamente da estrutura do seu organismo, seus órgãos e tecidos. Daí que na Física, depois de expostos os princípios gerais de transmutação da substância, considerasse não encontramos nas formas corpóreas e psíquicas alterações propriamente ditas, mas estados respeitantes a um cumprimento da sua potencialidade ou à sua degradação ${ }^{90}$. A tónica é colocada por Aristóteles na sensibilidade do organismo e da psique aos objectos e ao meio como causa da mutação subjacente ao cumprimento virtuoso ou vicioso do indivíduo. Esses são aspectos que Aristóteles desenvolve em sua obra ética, mas aqui conjuga o corpo, a psique e o desenvolvimento da sensibilidade:

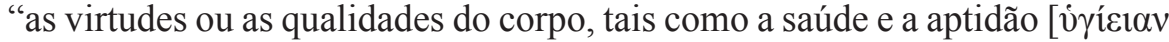

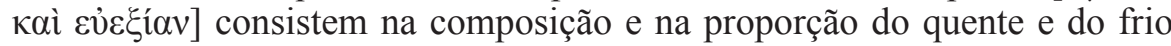

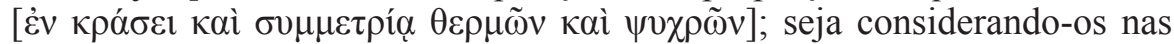

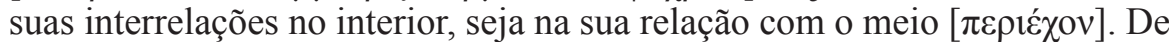
modo similar, consideramos a beleza, a força e todas as demais virtudes e

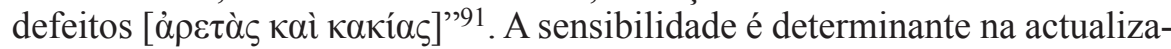
ção dos estados corpóreos mas também das afecções e disposições da alma. $\mathrm{Na}$ sensibilidade se fundam selecções que procedem a partir da distinção entre o relevante e o indiferente e entre o agradável e o doloroso pois: "toda a virtude ética é relativa aos prazeres e às dores do corpo"92. Para a psique, a sensibilidade corpórea imediata é primordial mas é inserida nas disposições corpóreas e psíquicas por intermédio da memória e das projecções, daquilo que o indivíduo recorda e daquilo que espera e anseia. Na ética aristotélica o prazer tem um papel central na formação do carácter, mas para ser virtuoso deve ser consistente com o que a razão recta apresenta como desejável. Esse discernimento tal como na ciência requer uma boa disposição do corpo, em

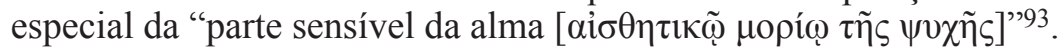

Em Da História dos Animais demonstra Aristóteles uma familiaridade inequívoca com a estrutura fisiológica subjacente à circulação dos quatro humores e da sua combinação proporcional como base do estado de saúde ideal ${ }^{94}$. Mas na sua ideia de $\kappa \rho \tilde{\alpha} \sigma ı \varsigma$ ou "composição", que é para Aristóteles um dos tipos de mistura $[\mu i ́ \xi 1 \zeta]$, não remete para aqueles fluídos e privilegia as variações de temperatura (quente-frio) e humidade (seco-húmido).

90 Cf. Phys. VII, 3, 246a $10-246 \mathrm{~b} 2$.

91 Phys. VII, 3, 246b 3-7.

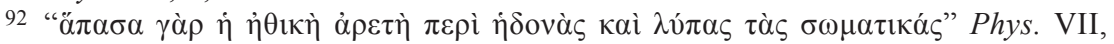
247 a 7.

93 Phys. VII, 3, 248a 9.

94 A centralidade dos humores e sua mistura proposta em Da Natureza do Homem, bem como os efeitos dos vapores no organismo não seria desconhecida de Aristóteles, contudo, em derivação do seu tratamento da filosofia natural, nos trabalhos dedicados a questões fisiológicas e também ao psicofisiológico privilegia as qualidades capazes de moldar os elementos do corpo, cf. Hist. An. 512b. 
Se é indubitável que associa a fraqueza e o desvio ou anormalidade com o melancólico, em Partes do Animais Aristóteles nunca chega a remeter para a bílis como causa daquela constituição ou temperamento, pois a mesma (bílis) é um excedente ou resíduo $[\pi \varepsilon \rho ı \tau \tau \mu \mu \alpha$ que não tem em si mesmo um propósito, havendo vários animais, incluindo certos humanos, que não têm sequer vesícula biliar que a segregue. Contudo, resíduos como a bílis e a flegma podem, em conjugação com outros, ter proveito para o corpo, remetendo o texto para uma função de purificação que tem lugar nos animais cujo sangue é impuro e acre, complementando a acção do baço ${ }^{95}$. Ou seja, Aristóteles concebe esses resíduos como derivados de uma disfunção que leva ao desenvolvimento de certos recursos por parte dos organismos. A bílis negra é posta em complementaridade com as fezes e sua função excretora, mas não lhe é atribuído um papel similar ao que assume enquanto um dentre os Xvuoí no $C H$. Por outro lado, o termo $\pi \varepsilon \rho ı \tau \tau o \mu \alpha$ só mais tarde surgirá na literatura médica, e não possui ainda vincada a ideia de origem de doença ${ }^{96}$.

Se a melancolia é naturalmente fria e seca como sustenta o texto do $\mathrm{CH}$, isso não impede que sujeita a certas variáveis ela não possa ser alterável como se considera em Partes dos Animais ${ }^{97}$, ideia metabólica que irá suportar o edifício argumentativo do Problema $X X X$.

Sabemos como logo no livro primeiro do De Anima Aristóteles se manifesta crítico relativamente aos modos de investigar as afecções da alma $[\pi \alpha ́ \theta \varepsilon \mu \alpha \tau \alpha]$ apartando-as inteiramente do corpo $^{98}$, sem antes esclarecer de-

95 "Por isso o fígado, nos seres que não têm vesícula, tem uma boa cor e um paladar adocicado, pelo menos na generalidade dos casos; nos que a possuem, é a parte do fígado abaixo da bílis a mais doce. Se, pelo contrário, o sangue que entra na composição desse órgão é menos puro, a excreção que se produz é a bílis. Ora uma excreção pretende ser o contrário do alimento, e o amargo o contrário do doce; como o sangue doce é que é o saudável. Fica assim claro que a bílis não tem uma função própria, é apenas um resíduo" Aristóteles, Part. An., 677a, in Obras Completas, vol. IV, trad. Maria Sousa e Silva (Lisboa: INCM, 2010), 150.

96 Cf. Eijk, Medicine and Philosophy, 151-155.

97 Cf. Part. An. 648 a 20 e ss. Na verdade, no $C H$ considera-se que a bílis negra pode altera as suas propriedades, desde logo a dimensão, com a transição entre as estações, expandindo-se do Verão e minguando no Inverno, cf. e.g. Nat. Hom. vii.

98 "Esforçam-se apenas, todavia, por dizer que tipo de coisa é a alma; acerca do corpo que a acolhe, nada mais definem, como se fosse possível, de acordo com os mitos

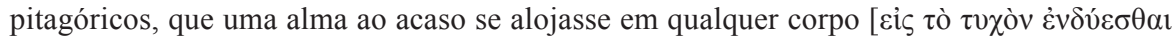
$\sigma \tilde{\omega} \mu \alpha]$. É que cada coisa parece possuir forma específica - quer dizer, estrutura — própria. Eles exprimem-se, no entanto, como se se dissesse que a técnica do carpinteiro se alojou nas flautas: é preciso, pois, que a técnica use as suas ferramentas, e a alma o seu corpo" De An. I, 3, 407b 20-25, in Obras Completas, vol. III, trad. Ana Maria Lóio (Lisboa: INCM, 2010), 47. 
vidamente a interacção entre estas e a eventual autonomia do intelecto relativamente aos órgãos sensórios e das faculdades perceptivas, volitivas e intelectivas ${ }^{99}$. Mas é nos seus escritos dedicados ao estudo da biologia que o filósofo investiga com algum detalhe o modo como as funções da alma estão suportadas na estrutura fisiológica. É no âmbito desse seu esquema psicofisiológico que deve ser considerada a sua abordagem da perturbação melancólica.

Na sua psicofisiologia defende o estagirita que a imobilidade da alma na recepção dos dados sensíveis é essencial para o bom processamento cognitivo. Esse pressuposto é quebrado em certos estados. O sono e a embriaguez, estados de alma irregulares caracterizados pela deposição da vigília e pela conturbação das faculdades volitivas e cognitivas, são adoptados como modelo compreensivo que descreve processos físicos semelhantes aos que são aduzidos na explicação da doença e do padecimento mental.

Em Acerca da Adivinhação no Sonho a explicação para a adivinhação atribuída àqueles cuja constituição física é melancólica não é o prodígio divino. Ela tem sua razão de ser numa maior agitação e susceptibilidade destes indivíduos ao sensório, sobretudo às imagens que tornam seus sonhos vívidos e distintos ${ }^{100}$. Também a maior frequência de tais sonhos inclina o melancólico a lançar-se na adivinhação o que lhe garante maior probabilidade de ter premonições que se concretizam ${ }^{101}$. Philip J. van der Eijk explicitou que a aptidão aqui operante é a 'euthuoneiria' que os melancólicos possuem e que consiste na "combinação da sua sensibilidade natural (fisiológica) e um grande número e variedade de movimentos ou imagens (phantasmata)"102. Mas o pequeno texto é inequívoco na sua atribuição de tal capacidade à própria simplicidade e debilidade mental, seguindo as reticências de Platão quanto aos prodígios de origem física. Ao mesmo tempo destaca a inexorabilidade do pensamento associativo naqueles indivíduos ${ }^{103}$. Faz questão de afirmar aí que a ser divina, a prática da adivinhação "sucederia ao sábio e teria lugar regularmente no período diurno"104.

Relato diverso é o contido em Acerca dos Sonhos, onde Aristóteles afirma que os melancólicos têm sonhos pautados pela distorção das imagens.

99 Cf. De An. 402a e ss.

100 Cf. Aristóteles, Div. Somn. 463b 12-22.

101 Cf. Div. Somn. 464a 27 - 464b 5.

102 Cf. Eijk, Medicine and Philosophy, 144.

103 De modo similar, também em Acerca da memória e reminiscência, o processo rememorativo é considerado em sua vertente física, pois revela-se autónomo relativamente

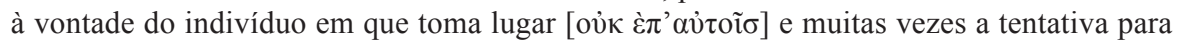
recordar é infrutífera afluindo as imagens já depois do esforço. Mem. et Rem. 453a 14-31.

104 Div. Somn. 462b 22. 
Essa particularidade parece ser explicável pela forma como os vapores ou gazes exalados pela digestão da comida e pela própria bílis negra parecem não só induzir o sono, mas também toldar a mente ${ }^{105}$. Estes vapores que atravessam o diafragma vindos do baixo-ventre aproximam-se da sede do intelecto, tal como o ar [ $\pi v \varepsilon \tilde{v} \mu \alpha]$ contido em certas substâncias (a bílis negra, o vinho e o esperma). Eles terão um efeito semelhante ao vinho no ébrio, e ao agravamento da condição febril ${ }^{106}$, contribuindo pela uma maior agitação das imagens apreendidas pela sensibilidade e convocadas pela memória e pela imaginação durante os sonhos. É uma tal alteração das substâncias que também no Problema $X X X$ está na origem de um acréscimo da temperatura em redor do órgão coordenador das funções vitais e origem do intelecto.

Também na Ética a Eudemo se admitia a concessão do dom divino àqueles cuja razão está de algum modo limitada ${ }^{107}$. Outra inconsistência pode ser encontrada na consideração da origem da irracionalidade própria dos melancólicos, umas vezes é atribuída à sua impetuosidade, outras à sua passivida$\mathrm{de}^{108}$. Contudo, esta contradição poderá ser dissolvida se for tida em conta a dinâmica garantida pela metabolização outorgada à bílis.

À semelhança do exposto nos Parva Naturalia e na Ética a Eudemo, no Problema $X X X$ será subscrita a sensibilidade ao movimento e às imagens como marca distintiva do melancólico, base dos dons proféticos e da sobreexcitação, efeitos da acção do calor no organismo e em especial em redor do

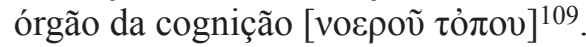

Em Partes dos Animais o sobreaquecimento do organismo fora atribuído à incapacidade do cérebro para resfriar o calor dos fluídos, aspecto mencionado como origem das perturbações e doenças do intelecto [voṽ $\varsigma]^{110}$. No mesmo tratado, é destacada a importância de uma característica dos animais superiores que permite a fronteira entre o centro sensório e cognitivo e os órgãos inferiores, onde se processa a nutrição: "o diafragma serve de separador

105 Cf. Aristóteles, Insomn. 460b 28 - 462a 7.

106 A evidência da persistência do estado melancólico e a transitoriedade dos estados febril e embriagado não é abordada nesse tratado.

107 Cf. EE 1248a 40 - 1248b 1.

108 Cf. Div. Somn. 463b 17-22.

109 Cf. Aristóteles, Probl. 954a 31-8. A influência de tal texto em toda a tradição posterior levou R. Klibanski, E.Panofsky e F. Saxl a optarem pela sua transposição integral para Saturno e Melancolia, seu estudo conjunto, numa tradução que optamos por não seguir devido ao seu excessivo lirismo.

110 Cf. Part. An. 653b. "Um cérebro demasiado húmido ou demasiado seco não cumpre bem a sua função; ou não arrefece o sangue ou o faz coagular, a ponto de provocar doenças, a loucura ou mesmo a morte. É que o calor no coração, que é o princípio, é muito susceptível e ressente-se imediatamente das alterações ou afecções que o sangue sofra na região cerebral" Part. An. 672b, in Obras Completas, 79. 
entre a cavidade abdominal e a região do coração, de modo a que o princípio da alma sensível não sofra qualquer lesão: nem seja directamente atingido pela exalação proveniente dos alimentos, nem pelo excesso de calor que eles libertam. Foi com esse objectivo que a natureza criou uma separação, fazendo do diafragma uma espécie de parede ou barreira, de modo a isolar uma parte nobre de outra menos nobre, em todas as espécies em que é possível separar uma parte superior de uma inferior"111.

Aqui se privilegia a potencialidade das substâncias mediante sua relação com o processo digestivo, a homeostase da temperatura (mediante o aquecimento dos fluídos pelo coração e a função de refrigeração do cérebro) e sua distribuição nos diferentes órgãos, mas na Ética a Nicómaco admitiu Aristóteles que determinados estados emocionais mais intensos, certas paixões como a raiva ou a excitação sexual, podem ocasionar patologias como a mania ainda que de modo transitório ${ }^{112}$.

\section{A constituição e o carácter melancólico na ética aristotélica}

Na obra ética de Aristóteles a saúde é tomada como modelo normativo, explorando-se "o modo como a analogia médica suporta a pretensão de que na ética, valores como o bem e o prazer, são objectivos [têm uma objectividade], e a ideia de que existem especialistas que se podem pronunciar com autoridade acerca do assunto"113. Contudo, contrariamente ao modelo teórico platónico onde os valores morais estão à partida estabelecidos, restando aceder-lhes por via do discernimento racional-intuitivo, para Aristóteles as aspirações do indivíduo na vida e na sociedade são tomadas como fontes dos conceitos de virtude e excelência ${ }^{114}$. Por outro lado, o modelo aristotélico de inquérito moral, que toma a ética como um processo interminável que requer a observação da participação, debate e negociação dos agentes, desacredita a hipótese do acesso a verdades de modo contemplativo, a ideias que se aproximariam de fórmulas matemáticas que competiria ao filósofo transpor para o mundo sensível. Daí que, à imagem do que ocorre com os princípios que permitem explicar os fenómenos do mundo sensível caracterizado pela

111 Part. An. 672b, in Obras Completas, 134.

112 Cf. Eth.N. VII 1147 a 15 e ss.

113 Geoffrey E. R. Lloyd, In the Grip of Disease. Studies in the Greek Imagination (Oxford: Oxford University Press, 2003), 181.

114 Sigo aqui a contraposição entre "sistemas filosóficos" proposta por Martha C. Nussbaum. Contraposição recentemente actualizada pela filósofa na sua revisitação à obra de 1994: The Therapy of Desire: Theory and Practice in Hellenistic Ethics (Princeton, NJ: Princeton University Press, 2009). 
mudança e o efémero ${ }^{115}$, também na ética os postulados axiológicos possuam uma natureza distinta daquela que caracteriza os axiomas geométricos e matemáticos.

Logo no início da Ética a Nicómaco afirma Aristóteles que, à semelhança do arqueiro, tanto o indivíduo como a comunidade carecem de um alvo para o qual direccionar as suas actividades ${ }^{116}$. Mais tarde, já no livro sexto, o filósofo inclina-se para a ideia de que esses alvos estão já dispostos, sendo somente necessário ajustar a percepção dos mesmos. Devido à imaturidade, à doença ou à ignorância, origem de falhas morais, o indivíduo pode ser incapaz de conceber o trajecto para a eudaimonia ${ }^{117}$.

$\mathrm{Na}$ ética aristotélica ressurge o conceito de meio-termo numa acepção diversa da ideia de moderação e adequação entre o regime e a constituição

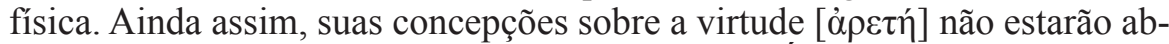
solutamente cindidas da ideia de equilíbrio físico. É a $\varphi \rho o ́ v \eta \sigma ı \varsigma, ~ c a p a c i d a d e$ de exame e ponderação dos valores e do curso da acção, que assegura a regulação adequada dos apetites imediatos e dos desejos caprichosos e, como tal, o cultivo das várias virtudes do homem. É no meio-termo entre o excesso e o defeito de uma determinada paixão que se encontra a virtude, por exemplo a coragem, entre a cobardia e a temeridade, ou a generosidade, entre a avareza e o despesismo ${ }^{118}$. Logo no segundo livro da Ética a Nicómaco, Aristóteles desenvolve analogias referentes à doutrina do meio-termo, sublinhando sempre a ideia de uma objectividade do bem que, tal como na objectividade da saúde, é resultado de um equilíbrio sempre relativo. O excesso ou a falta de exercício, assim como o excesso ou o defeito no consumo de comida são sempre danosos para a saúde, mas a medida, que nunca deve suprimir inteiramente o prazer, varia de acordo com o indivíduo ${ }^{119}$. Não estamos em nenhum dos casos (na ética e na medicina) perante um relativismo absoluto. À semelhança do que ocorre no domínio ético, em que só o juízo do homem virtuoso pode fornecer a objectividade do bem, também na medicina, é no homem íntegro ou são que podemos encontrar os princípios básicos da higiene, ainda que só ao médico seja acessível a correlação exacta entre a constituição, as circunstâncias e a conduta dietética do Homem ${ }^{120}$.

115 Ver a este respeito o primeiro livro da Física, onde os princípios da natureza mutável são contrapostos aos dos geómetras, cf. Phys., I, 184b 27 e ss.

116 Cf. Eth.N. 1094a 22-24.

117 Cf. Eth.N. 1143b 18 - 1144a 11.

118 Cf. Eth.N. II, 1106b 16 e ss.; EE II, 2, 1220b 21 - 1221b 3.

119 Cf. Eth.N. 1006a 29 e ss.

120 Cf. Geoffrey E. R. Lloyd, "The role of medical and biological analogies in Aristotle's Ethics”, Phronesis, 13 (1968), 77 e ss. 
Tal como a medicina, a ética é prática e engloba o bem em sentido restrito, isto é, o bem para o indivíduo, o qual por sua vez, mediante correcção das disposições naturais, dos hábitos e dos prazeres, pode ser coincidente com o bem comum. Esta fundamentação da objectividade do bem requer uma árdua aplicação de princípios que até se podem afigurar "proposicionalmente" evidentes, mas o difícil é sua aplicação a um caso particular. A acção ética requer avaliações e decisões que implicam um certo grau de incerteza e imponderável, sendo impossível aceder ao bem através da dedução matemática ou do erigir de princípios absolutos. Como vimos a respeito de Da Medicina Antiga, a aferição da justa medida não prescinde de um sistema, mas este deve permanecer aberto à observação. $\mathrm{O}$ que está em questão nos textos médico-filosóficos de pendor terapêutico, é uma ideia de equilíbrio que não é de tipo aritmético nem inteiramente universal, mas relativo: "por meio refiro o que é equidistante de cada um dos extremos, que é sempre o mesmo para todos. O meio relativo é para nós o que não é nem pouco nem demasiado, e este não é único nem o mesmo para todos"121. Já na Etica a Eudemo, procede Aristóteles a um contraste entre os métodos de inquérito que caracterizam a geometria e a astronomia, que visam um saber independente dos anseios humanos, e o que é próprio da medicina e política, nas quais não se busca só conhecer mas atingir ou, pelo menos, propiciar um certo estado ${ }^{122}$. É na sequência à crítica à concepção platónica de bem que no livro quinto da Ética a Nicómaco se avança com a comparação com a administração de substâncias e cuidados na medicina: "ainda que seja fácil saber o que são o mel, o vinho, o heléboro, a cauterização e o uso da faca, saber como, a quem e quando devem ser aplicados para produzir saúde não é menos difícil do que ser médico"123.

Mas como refere Aristóteles de modo detido na Ética a Eudemo, há também restrições à abrangência do paralelismo entre o tipo de cura ou cuidado de si por via do exame e construção de argumentos que caracteriza o procedimento terapêutico da ética e a medicina. Esta limitação é decisiva para integrar correctamente a sua compreensão dos melancólicos. De acordo com o filósofo, tanto as crianças como os loucos não estão aptos para receber e integrar argumentos éticos uma vez que suas faculdades racionais são diminutas, estando as primeiras carentes de formação e os segundos de correcção

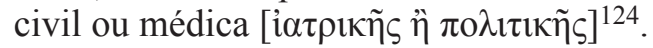

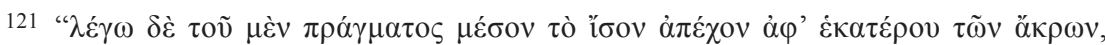

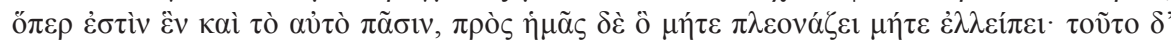

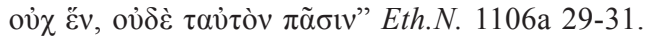

122 Cf. EE I, 5, 1216b 15 e ss.

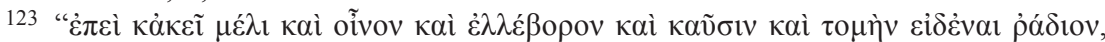

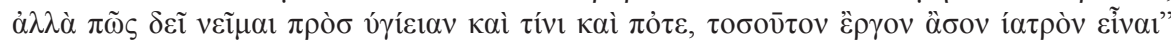
Eth.N. V, 9, 1137a 13-16.

124 Cf. EE I, 2, 1214b 29-35. 
Existe uma outra distinção entre filosofia moral e saber médico, ao passo que neste há uma consistência entre os desejos (e anseios) do paciente e o fim da terapia e uma entrega tácita nas mãos do outro, na ética, sobretudo devido ao poder de crenças e costumes danosos, os anseios individuais podem frequentemente ser parte da própria etiologia do mal-estar. Ao mesmo tempo, deve notar-se que a atestação da eficácia de ambas as abordagens tem como elemento fundamental o discurso e o comportamento individual.

Outro tipo de analogias a que Aristóteles recorre passa pela classificação das constituições recorrendo aos termos médicos e contrapondo o que é concordante com a natureza ao desviante ${ }^{125}$. Nos casos mais extremos de distúrbio da percepção, da fantasia e do intelecto devidos a doença, Aristóteles julga que as paixões não podem ser enquadradas na ética da virtude uma vez que a mesma exige um grau de racionalidade que permita estabelecer nexos entre o comportamento, a representação do valor e o carácter ${ }^{126}$. Por seu turno, as acções involuntárias dos seres providos de razão, são sempre consideradas negativas podendo decorrer de coerção ou da ignorância. Mas têm uma dimensão ética pois são passíveis de imputabilidade moral e legal, ao mesmo tempo que a maior parte das vezes permanecem abertas a arrependimento e à correcção por parte dos indivíduos em que têm lugar. Para ser virtuosa a acção requer em Aristóteles a participação efectiva do indivíduo e a sua deliberação, sendo que a responsabilidade e a eventual punição só pode ser deduzida quando nalgum momento foi possível ao sujeito controlar

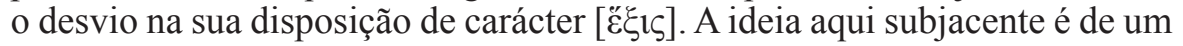
agravamento que se torna irreversível, claramente presente no caso do vício, mas que a dado momento o indivíduo esteve em condições de contrariar ${ }^{127}$. Obviamente que, à semelhança do que ocorre no agravamento da doença, a partir de um certo momento isso será possível somente por via do auxílio prestado por outrem, por norma o médico, o qual sempre requer a colaboração do próprio paciente ${ }^{128}$.

125 Por exemplo, a respeito do prazer que deve ser tomado como real, contraposto ao

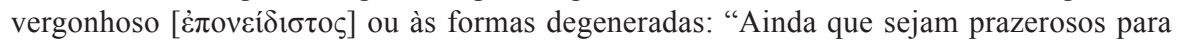

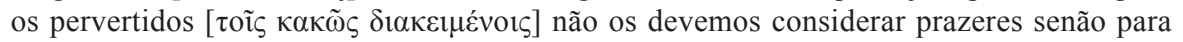
eles, tal como não o dizemos acerca do que os doentes [Kó $\mu v o v \sigma ı v]$ consideram saudável,

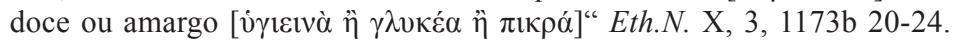

126 Eth.N. III, 5, 1114a 21 e ss.

127 Caso de viciação pelo reforço dos hábitos que é comparado por Aristóteles ao

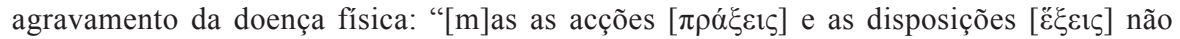
são voluntárias da mesma forma; pois somos mestres de nossas acções do início ao fim, se conhecermos os factos, ao passo que, ainda que controlemos o início das nossas disposições o seu progresso gradual não é [à partida] evidente, à semelhança do mal-estar $[\dot{\alpha} \rho \rho \omega \sigma \tau \hat{\imath} v]$; pois esteve em nosso poder agir desta e não daquela maneira, portanto as disposições são voluntárias" Eth.N. III, 1114b 28-1115a 2.

128 Cf. Eth.N. III, 1114a 14-16. 
Já no livro terceiro da Ética a Nicómaco, enquanto destaca as condições em que é possível imputar responsabilidade ao indivíduo pela sua disposição moral e acções, Aristóteles remete para o contrair de uma condição ou doença como ilustração de um ponto de irreversibilidade na constituição do hábito. Aristóteles utiliza a famosa imagem do sujeito que depois de lançar uma pedra já não poderá, independentemente da sua vontade e esforço, suspender o seu movimento e eventual dano ${ }^{129}$. Como refere o grande estudioso de Aristóteles Hellmut Flashar, também a melancolia se conjuga sempre no pretérito imperfeito ("Hätte ich doch..."), num momento volvido e inalterável mas que afecta todas as modalidades da experiência de si $i^{130}$.

É curioso que nas obras éticas os melancólicos não sejam caracterizados primeiramente como indivíduos deprimidos, o que seria consistente com a tradição, mas impulsivos, incapazes de conter e regular o seu apetite [غ̇лı $\theta v \mu i ́ \alpha]$. Assim retrata no livro VII da Ética a Nicómaco essa condição que tem origem na debilitação da capacidade deliberativa, no que se convencionou traduzir

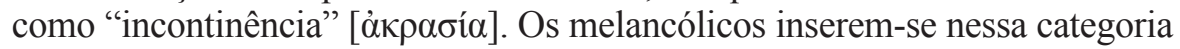
como aqueles que seguem as suas inclinações ou volições, agindo sem deliberar [ $\pi \rho 0 \pi \varepsilon ́ \tau \varepsilon ı \alpha]$, distintos dos que, ainda que capazes de deliberar, têm uma

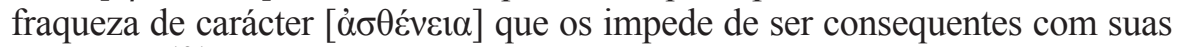

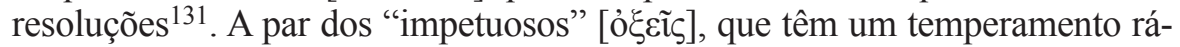
pido, os melancólicos enquadram-se naquele primeiro tipo, agindo em ante-

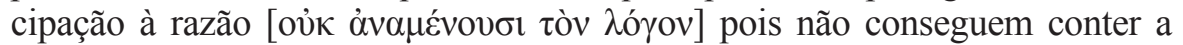
violência das paixões que os dominam, sendo propensos a seguir a fantasia $[\varphi \alpha v \tau \alpha \sigma i ́ \alpha]$.

Deve ter-se também em conta que além desta divisão entre o continen-

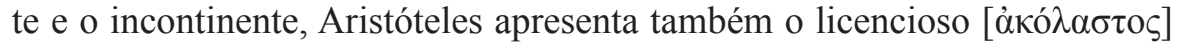
como o indivíduo cuja disposição o mantém na procura dos seus apetites de modo resoluto, imune às paixões morais -e seus constrangimentos- e sem arrependimento $^{132}$.

Refere adiante, de modo lacónico, que dentre as perturbações próprias da $\dot{\alpha} \kappa \rho \alpha \sigma i ́ \alpha$, aquela cujos tratamento [củı $\left.\alpha \tau \tau \tau^{\prime} \rho \alpha\right]$ e cura se afiguram mais fáceis é a do melancólico ${ }^{133}$. E acrescenta também que a incontinência adquirida por hábito $[\dot{\varepsilon} \theta 1 \sigma \mu o \varsigma]$ é mais fácil de curar que aquela que é congéni$\mathrm{ta}^{134}$. Esta ideia poderá parecer contraditória, mas Aristóteles estaria a referir

129 Cf. Eth.N. III, 1114a 15-21. Acerca desta famosa passagem ver: Pigeaud, La maladie de l'âme, 301.

130 Cf. Flashar, Melancholie und Melancholiker, 15.

131 Cf. Eth.N. VII, 7, 1150b 19-28.

132 Cf. Eth.N. VII, 1146b.

133 Cf. Eth.N. VII, 10, 1152a 27.

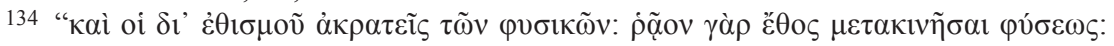


o temperamento melancólico como ह̌̋ı adquirido pelo hábito, contrastante com a constituição natural ${ }^{135}$. É neste ponto que, como assinalou Teun Tieleman, o filósofo avança com um método terapêutico bem revelador da intersecção da dimensão fisiológica e dos mecanismos volitivos subjacentes aos desejos impulsivos. Trata-se de um exercício de antecipação das causas e efeitos do forte desejo, exercício imaginativo realizado na ausência do seu objecto. Ainda que não desenvolva tal técnica, que antecipa o exercício estóico do proendemein, a sua referência é significativa da admissão da possibilidade de intervir numa condição fisiológica por via de uma alteração da disposição ética e mental do individuo ${ }^{136}$. Mas aqui, como noutros pontos da obra Aristóteles parece coibir-se de avançar demasiadamente num domínio que estaria já claramente autonomizado, a arte médica.

Não obstante tal debate do tratamento da doença ou vício de tipo melancólico, mais adiante a melancolia é afirmada condição inata caracterizada por uma contínua necessidade de alívios: "os melancólicos por natureza carecem sempre de unguentos pois, devido à sua composição, seu corpo é totalmente fustigado, estando à mercê do desejo violento. Mas a dor é expurgada ou pelo prazer oposto ou pelo acaso de o prazer ser forte. Assim se tornam indisciplinados e maus" 137.

Ao mesmo tempo que aqui se abstém de avançar com detalhes fisiológicos, insiste Aristóteles no contentamento que tende a acompanhar o jovem no seu crescimento, comparando-o com a transformação ocorrida no ébrio, destacando também aqui o peso que as estações da vida têm na modelação do carácter ${ }^{138}$. Esta ideia de uma transformação do carácter tem apoio nas teorias fisiológicas de Aristóteles. Por outro lado, a perda de capacidades mentais e cognitivas não decorre de um definhamento do intelecto que permanece íntegro, mas das partes físicas da alma. Nelas apresenta a contraposição entre os estados mais quentes, associados com a juventude e o arrefecimento que acompanha o envelhecimento. "O entendimento [voũs], no entanto, parece

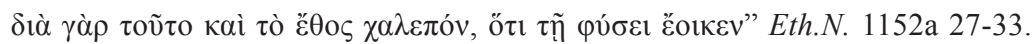

135 É possível que essa consideração da melancolia adquirida tenha influenciado a distinção operada na Magna Moralia (1293b 1-2) entre os que são impetuosos - os quentes e os normais - e os que são condenáveis - os frios e melancólicos -.

136 Teun Tieleman, "Nicomachean Ethics VII. 9 (1151 b 23) - 10: (In)Continence in Context", in Aristotle: Nichomachean Ethics, Book VII Symposium Aristotelicum, ed. Carlo Natali (New York: Oxford University Press), 180-181.

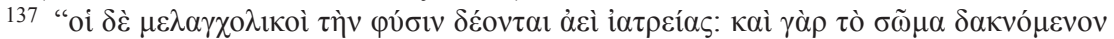

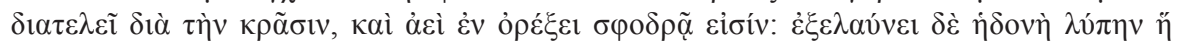

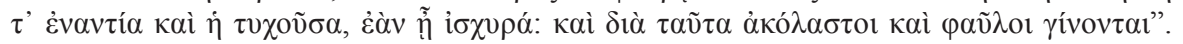
Eth.N. VII, 14, 1154b 12-16.

138 Cf. EthN. 1154b 10-12. 
ser, na origem, uma certa substância que existe e não estar sujeito a corrupção pois, caso pereça, será acima de tudo pelo enfraquecimento na velhice. Acontece, porém, como no caso dos órgãos sensoriais [ $\alpha i \sigma \theta \eta \tau \eta \rho i ́ \omega v]$ : se um ancião arranjasse um olho apropriado, veria como um jovem. A velhice não se deve, consequentemente, ao facto de a alma ser afectada [ $\pi \varepsilon \pi \mathrm{ov} \theta \dot{\varepsilon} v \alpha l]$ de alguma maneira, mas sim ao facto de ser afectado aquilo em que ela está, como é o caso da embriaguez e das doenças [vófors]. O entender e o contemplar perecem com a destruição de algum outro órgão interno, mas o entendi-

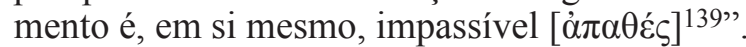

Pode ser lido em Aristóteles um outro modelo de análise e compreensão do restabelecimento da perturbação ou distúrbio mental. A ideia de кá $\theta \alpha \rho \sigma ı \varsigma$ apresentada na Poética e desenvolvida na Política, à imagem do que ocorre com a ideia de $\varphi \alpha ́ p \mu \alpha \kappa o v$, pode remeter tanto para o domínio religioso e ritual como para a acção médica de purificação. Mas ela contrasta com a concepção de terapia em que a correcção da condição médica, em especial no domínio do distúrbio mental, é eminentemente repressiva da parte apetitiva do homem. Tal como no Problema $X X X$, a ideia de "purificação" remete para o restabelecimento de um equilíbrio (que aqui incide nas emoções) que vai além de uma aplicação estritamente terapêutica e passa pela promoção ou potenciação de uma condição excepcional inacessível à maioria dos homens $^{140}$.

\section{O Problema XXX e a excepcionalidade}

A tradição filosófica tem no Problema XXX um dos grandes exemplos da recorrente tentativa de apagar ou mascarar as diferenças e descontinuidades entre o orgânico e o mental ${ }^{141}$. A inexistência de uma distinção clara entre os conceitos de "mente" e "corpo" em muitos dos escritos médicos da anti-

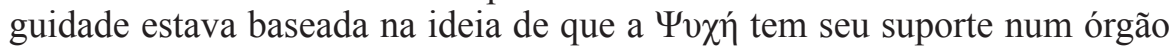
onde ocorrem processos físicos na base das funções perceptivas e cognitivas, susceptível à ingestão de produtos e ao exercício. Por vezes, além desse contínuo expressivo que permite observar o indivíduo desde o nível orgânico ao psíquico e aos traços de caracter, encontramos a tese mais radical onde, além da correlação e manifestação entre o "nível composicional" e o "mental", se estabelece uma determinação rígida deste último a partir da constituição fisiológica e anatómica dos indivíduos.

139 De An. I, 4, 408b 19-26, in Obras Completas, 47.

140 Cf. Lloyd, In the Grip, 187-193.

141 Cf. Edmundo Balsemão Pires, "Génio e Individuação", Revista Filosófica de Coimbra 40 (2011), 337-394, esp. 355. 
Como vimos, no Corpus Aristotelicum, essa tendência está patente nas considerações do carácter típico daquele que tem um excesso de bílis negra. Mas só mesmo na Ética a Nicómaco, parece inclinar-se Aristóteles para considerar a melancolia como uma condição patológica, apresentando-a também como constituição natural que deve ser medicamente acompanhada, sob risco de agravamento dos seus sintomas nefandos ${ }^{142}$.

Há duas características recorrentes ao longo das passagens do Corpus onde Aristóteles discorre sobre o indivíduo melancólico e a substância melancólica na origem da semeiosis física e psíquica inerente. Uma delas é a impulsividade. O melancólico tende a agir antecipando-se ao exercício deliberativo que submete as apetições e desejos a critérios racionais, regulando-os. A outra característica é a sensibilidade acrescida do melancólico, sobretudo imagética, a qual parece dever-se em parte a um impedimento da razão e a um mecanismo compensatório do sofrimento decorrente do modo como os melancólicos são constantemente excitados pelas paixões. Face ao exposto, é evidente que Aristóteles é avesso a considerar o predomínio da bílis negra como conferente de qualquer tipo de vantagem, mesmo aquelas que lhe seriam vulgarmente atribuídas, como seria o caso da adivinhação, sucesso que entende como fortuito.

Assim, apesar da continuidade e congruência que podemos apontar entre as observações de Aristóteles e os Problemata, é inverosímil a ideia de que a tese de uma aptidão atípica exclusiva do melancólico, sustentada ao longo Problema $X X X$, tenha um antecedente nas ideias do filósofo. Essa circunstância, mas também uma referência do próprio texto, inclina vários intérpretes a atribuir a sua autoria ao peripatético Teofrasto ${ }^{143}$. O certo é que, já na antiguidade romana a abordagem será tomada como contribuinte para explicar não só a oscilação súbita entre estados de espírito opostos, mas também a excelência improvável ${ }^{144}$. Interpretação que nos Problemata se encontra suportada na ideia de que a substância psicoactiva não se manifesta de forma unívoca mas numa variabilidade quantitativa e qualitativa. Essas variáveis dotam a bílis negra de uma potencialidade que a habilita a tomar parte na explicação do dinamismo do psiquismo humano.

Há com certeza uma similitude com Platão, mas o estudo da condição

142 “Ainda assim, Aristóteles só teve em vista a excitação tempestuosa dos melancólicos e não os sintomas depressivos" Flashar, Melancholie und Melancholiker, 60.

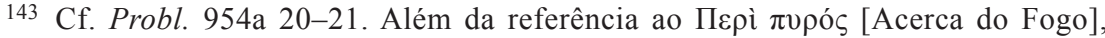
obra homónima de Teofrasto, a atribuição tem como suporte uma menção de Diógenes Laércio a um tratado sobre a melancolia do mesmo autor. Cf. Flashar, Melancholie und Melancholiker, 61; Klibansky et al., Saturn and Melancholy, 29-37.

144 Um dos mais célebres exemplos é a apresentação da oscilação entre a tristeza e a exaltação no melancólico presente no capítulo III das Tusculanae Disputationes de Cícero. 
mental tem na tradição aristotélica maior abrangência se considerarmos a incidência detalhada na dimensão fisiológica e a gama de padecimentos abordados. Mais importante, Aristóteles desconsidera aspectos religiosos da equação da origem da doença e dos estados mentais aos quais procura oferecer uma base fisiológica coerente e com capacidade explanatória.

Se a partir da leitura do texto a questão clássica de saber se existe uma norma que permita identificar o modo patológico tem uma resposta talvez insatisfatória, em compensação resulta indubitável que "existe também uma saúde do melancólico"145. A posição do tratado é de que a condição melancólica pode ser congénita, caso em que a constituição ou temperamento indivi-

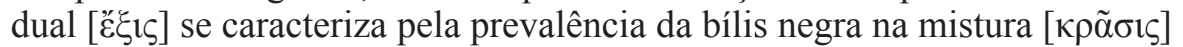

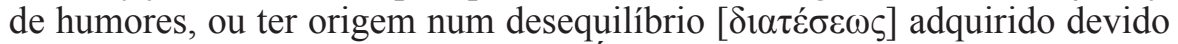

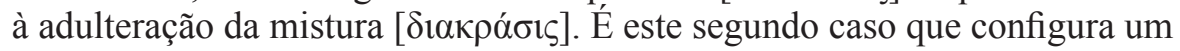
estado patológico, sendo que o autor segue a ideia difundida na antiguidade de que os factores dietéticos são a origem mais frequente do desequilíbrio, ainda que, por vezes, também as paixões sejam consideradas na etiologia. Em consonância com a distinção clássica apresentada no $\mathrm{CH}$, para o autor do Problema $X X X$ o temperamento melancólico é crónico ao passo que a doença, quando devidamente acompanhada, é transitória.

A interrogação que inicia o texto ("Porque é que todos os homens que se tornaram excepcionais em filosofia, política, poesia e artes se afiguram melancólicos[?]") contém já em si mesma a resposta, os homens excepcionais [ $\pi \varepsilon \rho ı \tau \tau$ i $]$ padecem de melancolia, mas de um tipo bem peculiar, da sua variante congénita. Esse tipo distingue-se das formas comuns inseridas na síndrome com manifestações sintomáticas senão debilitantes (como a epilepsia, a misantropia, a depressão e o suicídio, mencionados no texto) pelo menos indesejáveis e não ideais. No texto distingue-se entre a doença, que pode acometer qualquer indivíduo independentemente de sua constituição e a condição melancólica propriamente dita, sendo que, os indivíduos enquadrados nesta última, devido à sua constituição natural, estão mais susceptíveis aos seus padecimentos característicos ${ }^{146}$. Por outro lado, só um número muito restrito dentre esses indivíduos pode almejar o acesso aos picos de performance nas diferentes áreas de acção.

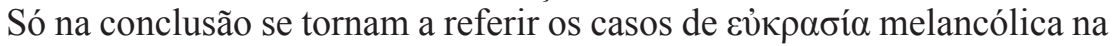

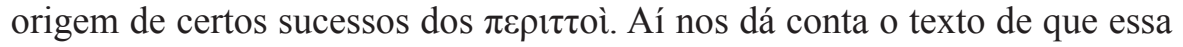
condição é possível por força da manutenção de uma temperatura equilibrada, mas não existe antes desse ponto a indicação de um reajuste "automático" da temperatura consoante as exigências levantadas por uma situação

145 Pigeaud, La maladie de l'âme, 263.

146 Cf. Probl. XXX, 953a 12-15 e 29-31. 
individual ${ }^{147}$. Veja-mos com maior detalhe o mecanismo térmico proposto.

Apesar de ser considerada fria no seu estado natural, a bílis negra altera suas qualidades quanto submetida a temperaturas mais elevadas. $\mathrm{O}$ autor estabelece um paralelismo não só com a água que é considerada naturalmente fria, alterando seu estado quando submetida ao calor, entrando em ebulição,

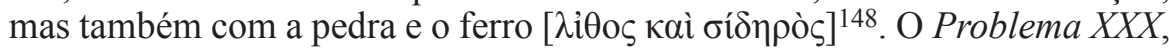
é omisso quanto à possibilidade de estados emocionais interferirem directamente na qualidade da substância, se bem que o cérebro, responsável pela refrigeração do sangue e dos resíduos, possa tornar-se menos eficaz quando se verifica um aquecimento no órgão do intelecto.

As consequências psíquicas dos extremos térmicos da bílis negra verificam-se tanto na condição congénita como na adquirida. No caso da manutenção do estado natural (frio) da substância ela está na origem da disposição depressiva $[\alpha \theta v \mu 1 \alpha]$, bem como do torpor físico, da tristeza e da misantropia, ao passo que o sobreaquecimento leva a estados de êxtase, propiciando manifestações vitais como o apetite sexual e a expressividade, mas frequentemente aproximando-se dos estados maníacos ou de loucura

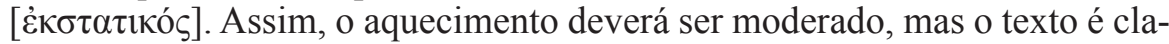
ro na ideia de que só o melancólico congénito poderá experimentar as manifestações faustas da melancolia indo além da mediania saudável e evoluindo para performances excepcionais.

O estado da bílis negra está dependente das oscilações na mistura entre frio e calor que variam de acordo com o seu excesso [ن̉ $\pi \varepsilon \rho \beta \alpha \dot{\alpha} \lambda \lambda \eta \dot{\varepsilon} v \tau \tilde{\omega}$ $\sigma \omega ́ \mu \alpha \tau 1]^{149}$, propício ao seu estado frio e à sua manutenção numa forma quase sólida e no interior do organismo. Já na sequência da ingestão de certos alimentos, primeiramente o vinho negro, a bílis negra inicia a sua efervescência e sobreaquecimento, mobilizando-se para a superfície do organismo. $\mathrm{O}$ primeiro dos extremos consiste na $\kappa \rho \tilde{\alpha} \sigma i \varsigma$ onde se encontram os indivíduos tomados pela $\dot{\alpha} \theta v \mu \dot{i}^{150}{ }^{15}$. A $\kappa \rho \tilde{\alpha} \sigma ı \varsigma \zeta$ do extremo oposto propicia estados "excêntricos" como mania e o furor. O conceito central neste último caso

147 Van der Eijk apresentou as dificuldades levantadas pelo modo como a frase final da primeira secção do Problema $X X X$ apresenta uma conclusão que nalguns pontos difere

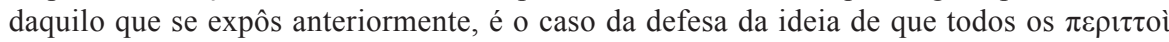
são melancólicos e também a tese de que tem lugar no melancólico uma adaptação da temperatura a situações específicas, cf. Eijk, Medicine and Philosophy, 156-157.

148 Cf. Probl. XXX, 954a 16-20. O ferro corresponderia melhor à imagem pretendida pelo autor pois no estado "natural" (frio) permanece contraído e quando submetido a calor distende-se.

149 Probl. 954a 22-24.

150 Estado depressivo que, olhando à globalidade do texto, parece poder agregar os

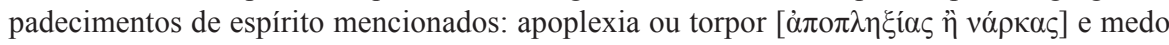
[ழóßovs], cf. Probl. 954a 24-25. 


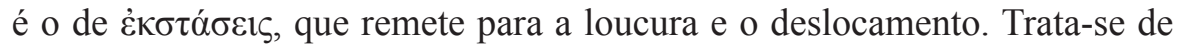
um êxtase que transporta, mas que pode ter consequências diametralmente opostas para o bem-estar. Ao mesmo tempo que a alegria que suscita dá azo

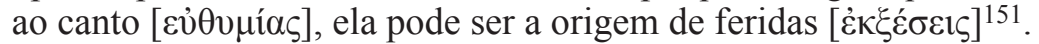

Aqueles extremos podem passar de estados passageiros para uma "designação rígida" do carácter individual, seja devido ao agravamento da condição (por causas inerentes à constituição física congénita) ou à persistência de hábitos danosos. Assim, no primeiro caso, aquele em que a bílis permanece em seu estado natural, as paixões letárgicas alastram-se a toda a actividade

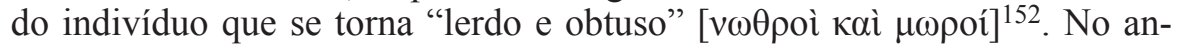
verso da síndrome, encontra-se o indivíduo que repetidamente experimenta o êxtase das paixões que acompanha o aquecimento generalizado, havendo também aqui lugar um processo de fixação do carácter. Neste caso admite

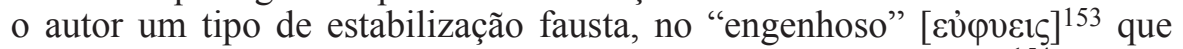
é posto a par do maníaco, do enamorado e dos verbosos $[\lambda \alpha ́ \lambda 01]^{154}$. Certos prodígios divinatórios e poéticos são possíveis só nesse êxtase, e à sua fugacidade estão confinados tais melancólicos.

É imediatamente após esta exposição dos extremos provocados pelas

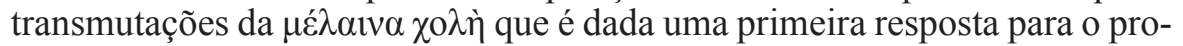
blema inicialmente exposto. Há certos indivíduos que acedem e subsistem numa performance de excelência por períodos extensos ${ }^{155}$. Eles tendem para

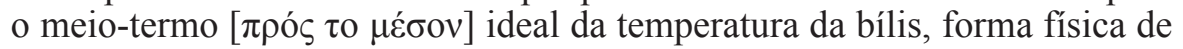
moderação que lhes confere superioridade em várias áreas. Porém, adverte-se que isso não significa que estejam imunes à oscilação própria da mistura $[\kappa \rho \tilde{\alpha} \sigma \iota \varsigma]$ se bem que a mesma tenha neles repercussões díspares, sendo referidas as situações que suscitam medo como "barómetro" diferenciador das manifestações emocionais daquela mistura ${ }^{156}$. Assim, parece resistir-se a uma total sobredeterminação do carácter moral e do psiquismo pela cons-

151 Cf. Probl. 954a 26-27.

152 Cf. Probl. 954a 31.

153 Termo que, inserido nesta sequência do texto e, tido em conta seu contexto, indica também o "astuto". Deve notar-se que, antes deste texto todas as evidências apontam para associação do melancólico com a doença e a morte, sendo provável que a constelação semântica em torno de certas manifestações patológicas tenha na verdade antecedido a diferenciação de uma forma de bílis dita negra, cf. Flashar, Melancholie und Melancholiker, 37; Vivian Nutton, Ancient Medicine (London: Routledge, 2004), 83 e ss. Vide supra nota 23 .

154 Cf. Probl. 954a 32-34.

155 Cf. Probl. 954a $39-954 b 4$.

156 Cf. Probl. 954b 6-8; 11-14. A asserção do factor psicológico é dúbia pois logo de seguida é estabelecida comparação entre as oscilações da melancolia e o estado quente ou frio da água, sendo a casualidade do encontro entre uma situação e a mistura corpórea que irá determinar a acção individual. 
tituição natural, concedendo-se -é certo que de modo reticente- a existência de factores psíquicos contribuintes para a instabilidade inerente à condição melancólica.

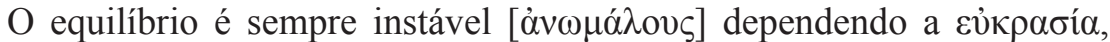

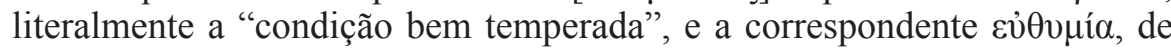
factores mutáveis que têm manifestação "ethopoiética", isto é, influem no carácter moral e nas aptidões psíquicas ${ }^{157}$.

É por via da analogia com o vinho ${ }^{158}$ que se torna evidente aos olhos de todos como o físico afecta a mente, provocando distintas reacções de acordo com a quantidade ingerida. A diferença é que, se no caso do éter a influência

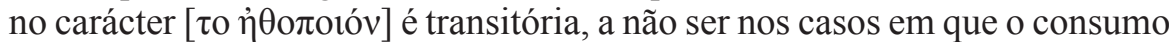
excessivo e continuado provoca alterações na disposição do caracter, no caso da bílis negra ela é permanente [ảsí] ${ }^{159}$. Mas a causa é a mesma: a temperatura como comando da produção de $\pi v \varepsilon \tilde{\mu} \mu \alpha$, que pode ser interpretado como princípio vital de movimento com manifestações tanto ao nível da agitação mental como do desejo sexual ${ }^{160}$. A espuma e as borbulhas que abundam no vinho, estão ausentes de produtos como o azeite ['̌́ $\lambda \alpha 10 v]$ associados à constância, e explicariam a efusividade do ébrio. Ocorrência semelhante tem lugar no esperma e é atribuída à bílis mediante o seu aquecimento ${ }^{161}$, o que

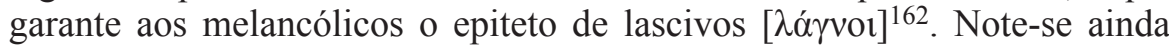
que, tal como o paroxismo sentido aquando da manifestação da temperatura ideal do organismo, também o alívio sexual, pela libertação do $\pi v \varepsilon v \tilde{\mu} \alpha$ acumulado, é temporário ${ }^{163}$.

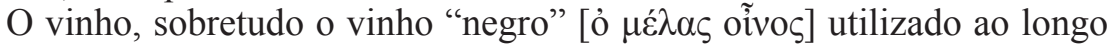
do Problema $X X X$, foi selecionado pois permite destacar a potencialidade e, neste caso, a multiplicidade de efeitos de uma mesma substância consoante a sua qualidade, a quantidade ingerida e a habituação ao consumo. O tema do excesso de consumo de vinho fora já abordado no livro III dos Problemata,

157 Muitos desses factores relacionam-se com aspectos discerníveis por observação empírica, é esse o caso da idade de um indivíduo. Outros, relativos à fisiologia, estão vedados à percepção directa, caso da dimensão (mas também da existência) de certos órgãos interiores como o coração, cujo tamanho é tido como forte indicador da coragem, cf. Part. An., 667a. É obviamente na Fisiognomonia, pequeno tratado peripatético, que essa correlação é feita entre aspectos específicos da estrutura anatómica e da postura, como o grau de verticalidade, a espessura do pescoço ou o tipo e distribuição das pilosidades, mencionados a respeito da coragem, cf. Phgn., 807a $30-807 \mathrm{~b} 12$.

158 Apresentada já anteriormente na Eth.N. 1154b 10.

159 Cf. Probl. 953b 17-23.

160 Cf. Klibansky et al., Saturn and Melancholy, 30.

161 Cf. Probl. 953b 28-33.

162 Cf. Probl. 953b 33.

163 Cf. Probl. IV, 880a. 
sendo retomado à maneira do Simpósio, como meio propício ao conhecimento aprofundado da alma, mas também por ser a substância que permite percorrer uma sequência de estados da alma ${ }^{164}$. Além de afectar o equilíbrio de modo temporário, à semelhança do que ocorre com a bílis negra aquecida, o vinho tem a presença de ar. O acréscimo deste elemento, desde tempos imemoriais associado à vitalidade dos seres, no corpo tem repercussões ao nível da disposição imediata do indivíduo.

O exemplo do vinho, é complementado pela analogia da idade, a qual figura na contraposição entre o carácter dos jovens e dos idosos presente na Retórica, acrescida da referência à idade adulta como pináculo das potencialidades vitais e psíquicas ${ }^{165}$. A embriaguez tem um ponto ideal no qual indivíduo se encontra imbuído de confiança tal como a criança, se bem que alguns mesmo bebendo permaneçam abatidos. A causa [aitíav] para tal dissonância é similar à que explica a depressão que se tende a apoderar depois do fim da bebida está dependente da constituição particular do indivíduo. O declínio abrupto da temperatura que então ocorre tem consequências nefastas, sobretudo nos idosos em virtude da sua temperatura inferior, mas também em todos quantos têm condição natural melancólica. Em tais casos, a depressão - da temperatura e do ânimo - é tão contundente que alimenta a inclinação ao suicídio ${ }^{166}$.

Daí que se enalteça a necessidade de cuidados profiláticos e terapêuticos constantes, pois ainda que os melancólicos tenham muitas vezes padecimentos prolongados, por vezes os sintomas escondem a sua real índole sob a capa da confiança, reemergindo furtivos e letais ${ }^{167}$ : "[m]as quando o calor é subitamente extinto pela primeira vez e a maioria dos homens se aniquila,

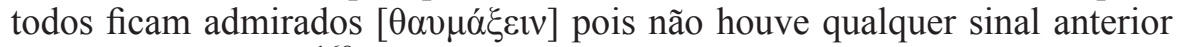
$[\sigma \eta \mu \varepsilon i ̃ o v \pi \rho o ́ \tau \varepsilon \rho o v]^{168}$ ".

No caso da maioria dos melancólicos o calor é salutar pois permite à bílis negra, substância psicoactiva, desencadear um processo de excitação dos fluidos que liberta o indivíduo da fixação e torpor dos seus apetites e paixões,

164 Cf. Pigeaud, La maladie, 495.

165 "Nos adultos, a temperança vai acompanhada de coragem e a coragem de temperança. Nos jovens e nos idosos estas características estão separadas: os jovens são valentes e licenciosos, os idosos moderados e cobardes. Falando em geral, tudo quanto de útil está repartido entre a juventude e a velhice encontra-se reunido no auge da vida; tudo quanto naquela há de excesso ou carência, esta possui-o na justa medida Quanto ao resto, o corpo atinge o seu auge dos 30 aos 35 anos, e a alma por volta dos 49." Aristóteles, Rhet., 1390b 2 e ss, in Obras Completas, vol. VIII, trad. Manuel Júnior et al. (Lisboa: INCM, 2005), 197-198.

166 Cf. Probl. 954b 36-37; 955a 9-10.

167 Probl. 954b 30-33.

168 Probl. 955a 11-14. 
na base dos estados depressivos ou do receio generalizado do contacto com o exterior. Daí que, para tal condição, o vinho, tomado como propício ao aquecimento geral dos órgãos, seja tido por benéfico pois contrapõe-se à frigidez própria do fluído ou resíduo melancólico. Já no caso das "doenças maníacas"

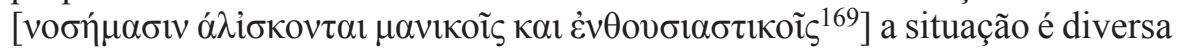
pois nestas um excesso de calor em torno do órgão intelectivo perturba a sensibilidade, conturbando os dados que vêm do exterior, e as faculdades da alma. Nesta é induzido um acréscimo danoso da sua velocidade, que culmina com formas de delírio e agitação psíquica e corpórea ${ }^{170}$. Daí que o vinho, benéfico no caso da melancolia seja nefasto para o maníaco, pois ao invés de reequilibrar a temperatura que o torna agitado e lhe afecta as capacidades sensório-motoras e a cognição, vai aumentá-la.

A ideia de impulsividade que na Ética se associa ao melancólico, aquele que não carece de capacidade de juízo mas cuja acção se antecipa ao exercício dessa faculdade, é retomada justamente a propósito dos homens excepcionais ou de génio. $\mathrm{O}$ conceito de génio presente no texto está dependente

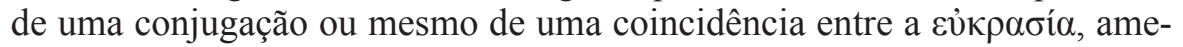
açada pela instabilidade do equilíbrio orgânico, e uma certa situação que requer esse mesmo equilíbrio. E a essa difícil sincronia que o génio consegue corresponder, agindo no momento exacto ou correcto ${ }^{171}$. É essa afortunada abertura à ocasião que está vedada aquele cuja acção se pauta pela prudência, mas se abre ao melancólico como homem de acção. Essa capacidade de observação e acção, antecipando-se à razão por via da concordância às circunstâncias será mais evidente no caso do governante e do estratega, sempre aptos a agir em estados de excepção e emergência (ou mesmo a desencadeá-los). Mas além dela, remete Aristóteles também para a capacidade estabelecer relações que se afiguram inverosímeis.

O que inequivocamente particulariza este texto é justamente a adopção da hipótese de uma constituição e temperamento inacessível pela via do há-

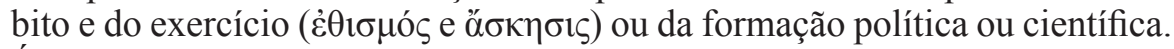
É uma forma de excepcionalidade natural que caracteriza a excelência do

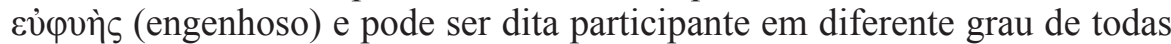
as virtudes ${ }^{172}$, mas tem também uma acepção no génio ${ }^{173}$. O que aqui está em causa é algo mais que aquilo que vulgarmente se entende por talento,

169 Probl. 954 a35.

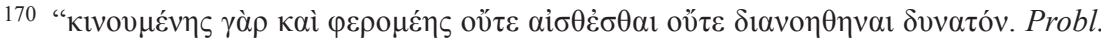
XXX 14, 957 a1-2. Cf. XXX, 14, 957 a2 e ss.

171 Como vimos, já na Ética a Nicómaco, a respeito do procedimento médico que pode

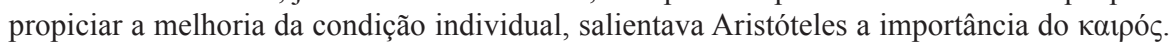

172 Cf. Eth.N. III, 5, 1114b 12.

173 Cf. Rhet. 1390 b 28. 
trata-se da ev̉pvía, qualificativo que surgia na Poética a respeito da capacidade dos mais geniais poetas para estabelecer as similitudes que suportam a metáfora ${ }^{174}$. O poder de associar de modo inovador ou impensado é característica do melancólico ${ }^{175}$. Essa capacidade é tomada como essencial para a actividade intelectual bem como para a filosofia, não implicando uma diminuição da razão mas a sua contribuição para a expansão da criatividade associada à fantasia ${ }^{176}$.

Ao filósofo, em particular, não bastam as capacidades estritamente analíticas, na formulação de proposições e argumentos. A capacidade especulativa requer não só o abandono da sua circunstância empírica e o extrair do fenómeno as associações causais que explicam a origem e a ordem das coisas, mas adicionalmente uma disposição criativa, capaz de correlações vedadas ao homem comum. A capacidade para superar o hiato entre a constatação e a inspecção das causas últimas separam os homens de génio dos

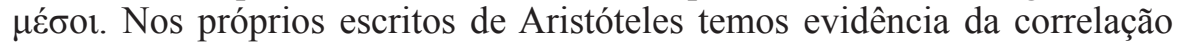
entre a fisiologia de um indivíduo e a sua inteligência e excelência moral. A Retórica contém a incursão mais detida abordando a questão da $\varepsilon u ̉ \gamma \varepsilon ́ v \varepsilon ı 1 \alpha$, remetendo para uma fundamentação fisiológica da descendência nobre que refere o modo cíclico em que nesta surgem os indivíduos excepcionais. Aristóteles mostra-se ciente de que além da boa constituição natural, propícia às virtudes, é necessária a sua preservação na disposição de si: "Por nobre

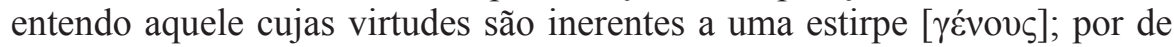
nobre carácter entendo aquele que não perde suas qualidades naturais. Ora, a maior parte das vezes, não é isso que acontece com os nobres, pelo contrário, muitos deles são de vil carácter. Nas gerações humanas há uma espécie de colheita, tal como nos produtos da terra e, algumas vezes, se a linhagem é boa, nascem durante algum tempo homens extraordinários [ $\pi \varepsilon \rho ı \tau$ ó$^{\prime}$, depois vem a decadência"177. Essa decadência assumiu a forma de loucura, nos

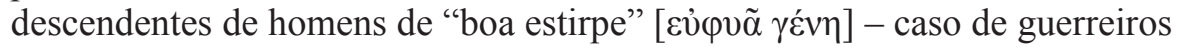
e políticos como Alcibíades e Dionísio I de Siracusa- e de indolência nos

174 Cf. Eijk, Medicine and Philosophy, 165. "Grande importância tem, pois, o uso discreto de cada uma das mencionadas espécies de nomes, de nomes duplos e de palavras estrangeiras; maior todavia, é a do emprego das metáforas, porque tal se não aprende

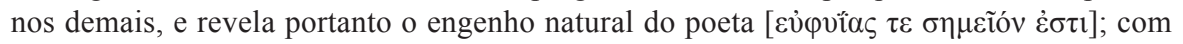
efeito, bem saber descobrir as metáforas significa bem se aperceber das semelhanças [ $\tau$ ò

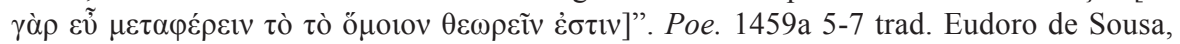
4ed. (Lisboa: INCM, 1986), 138.

175 Cf. Jackie Pigeaud "Une physiologie de l'inspiration poétique, de l'humeur au trope", Les Etudes classiques, 46 (1978), 23-31.

176 Cf. Rhet. 1394 a 5, 1412 a10.

177 Rhet. 1390b, trad. Manuel Júnior et al., in Obras Completas, (Lisboa: INCM, 2005), 198-199. 


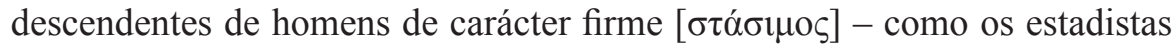
Címon e Péricles, mas também de Sócrates -.

Ainda aí, mas sem referência aos melancólicos, Aristóteles enaltece o modo como aqueles indivíduos se dividem entre os que tendem à loucura e os lerdos ${ }^{178}$, o que se conforma à oposição entre maníacos e depressivos, e sua coexistência no indivíduo bipolar, tese subjacente ao Problema $X X X^{179}$.

Vemos que, no Problema $X X X$ a exposição e o ensaio de esclarecimento da questão inicialmente apesentada, decorrem por via de uma "observação" mediada do desequilíbrio interior. A partir dessa observação, que conjuga ensaio médico e literário, é proposto um esquema geral onde constam as funções e as variáveis a ter em conta para conseguir reequilibrar qualquer organismo acometido pelo excesso de bílis negra. Contudo, o papel do médico, aquele que deve promover no outro a cura e eventualmente a potenciação das capacidades e aptidões individuais, permanece latente. Seria interessante entender o seu papel enquanto prescritor e, tendo em conta a relação assimétrica e ou cooperante com o doente, o modo como vem a influir ou a corrigir as convicções erróneas dos indivíduos quanto aquilo que contribui para o seu bem-estar. Para o exame médico é importante não só a disponibilidade mas a colaboração activa do paciente, pressuposto presente também em vários tratados hipocráticos. Essa colaboração activa pode mesmo dizer-se que deve anteceder aquele que pode ser o último recurso, o médico.

$\mathrm{O}$ crescente conhecimento e divulgação da influência de certos produtos na dieta, mas também a caracterização de determinados hábitos e desejos como danosos, leva ao surgir de um conceito de saúde cada vez mais fundado na responsabilidade do sujeito. A ideia de um temperamento ou constituição inata não é absolutamente inconciliável com aquele conceito uma vez que na constituição individual se inscrevem certas propensões e possibilidades que o próprio indivíduo ou o médico deverão saber interpretar. Nenhum indivíduo está imune às vicissitudes do acaso e não consegue suprimir inteiramente a sua vulnerabilidade física e mental, mas está-lhe reservado um papel na defesa face a certos factores patológicos, nomeadamente dos que se prendem com o conceito de Higiene já difundido entre os antigos ainda que correspondendo a uma ideia com aplicação mais generalizada e difusa, incidindo sobretudo no conceito de integridade. Nesse sentido é interessante sublinhar-se, com base em evidências históricas, que dentre as responsabilidades do pater familias fazia parte o conhecimento de princípios básicos de saúde e assistência médica ${ }^{180}$. No livro III da Política, na sequência da

178 Cf. Rhet. 1390 b, 27-30.

179 Cf. Probl. 954b, 28-34.

180 Ver a entrevista que P. van der Eijk concedeu em 2011 à revista $B K K i N$ FORM: "Gesundheit in der Antike" https://www.ruv-bkk.de/index.php?entryid=500 
apresentação da fundamentação da lei e da jurisprudência, Aristóteles comparava a legislação e o juízo em causa própria ao cuidado médico de si pró-

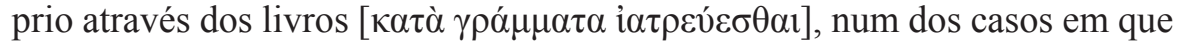

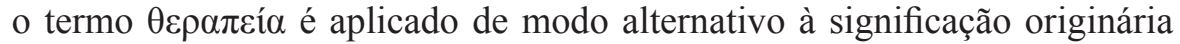
que o restringia ao tributo ou serviço prestado aos deuses. Só por motivo da quebra dos laços cívicos, comerciais ou de confiança na neutralidade do pro-

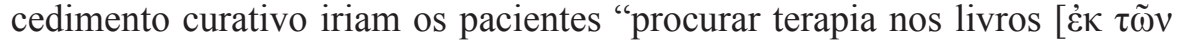

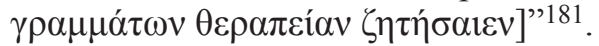

No âmbito do Problema $X X X$, a terapia só poderá mesmo respeitar à procura, antes de mais profilática e sempre sujeita a reajustes sem medida calculável de modo técnico, de um equilíbrio óptimo dos humores. A ideia de uma relação unívoca entre a substância e um certo efeito no organismo é questionada. Atente-se ao caso do vinho que pode desequilibrar negativamente a $\kappa \rho \tilde{\alpha} \sigma ı \zeta$ mas pode também contribuir para recalibrar a proporção dos humores ${ }^{182}$. Já na Ética era esta mesma variabilidade dos efeitos que obrigava a cuidados redobrados e constantes na administração de substâncias ${ }^{183}$. Tal ideia é herdada de concepções anteriores e privilegia a intervenção no meio físico por forma a restabelecer as funções de cada órgão ou faculdade. Assim, a patologia mental, seja a mania ou a melancolia, não se pode reduzir à sua dimensão estritamente sintomática, não só porque as combinações interiores dos humores, a sua distribuição e funcionamento em cada órgão estão ocultos, iluminados somente por analogias com fenómenos físicos observáveis (neste caso os efeitos discerníveis no comportamento), mas também porque se verifica uma dificuldade acrescida em distinguir entre as causas e as manifestações em torno das quais se tecem as queixas.

A escola peripatética fornece uma concepção dinâmica de doença, como o atesta a insistência, em diferentes pontos do texto, no carácter instável das manifestações melancólicas, em especial do génio, sempre em risco de deslizar para os extremos da tristeza e da loucura. Toda a observação da melancolia, tanto nas suas manifestações mais comuns como na excepcionalidade, indica como impossível a actualização num mesmo indivíduo de toda a sintomatologia que se foi avolumando no quadro nosológico. Mas toda essa sistematização está fundamentada em correlações entre as manifestações sintomáticas e os estados fisiológicos. Tal pendor "fisicalista" na descrição da melancolia, assegura que, subjacente à manifestação da genialidade, não está um processo epigenético mas uma estrutura fisiológica inata. Não obstante, a origem auto-referêncial no corpo do melancólico não significa uma estabi-

(consultado em 10 de Março de 2014). Cf. tb. Lloyd, Demystifying mentalities, 30.

181 Pol. III, 16, 1287a 40.

182 Cf. Probl. 955a.

183 Eth.N. VII, 14, 1154b 11. 
lidade da $\kappa \rho \tilde{\alpha} \sigma ı \varsigma$ nem a sua evolução expectável, ainda que o pressuposto de um contínuo entre os estados do corpo e os estados mentais, seja o que a tradição irá reter da leitura da melancolia fornecida pelos autores hipocráticos e pelo próprio Aristóteles. No Problema $X X X$ é a capacidade de regulação térmica, cuja esquematização tem antecedentes na obra aristotélica, que está na origem dos padecimentos do melancólico, mas também do dom de estar à altura dos eventos, marca da distinção face aos homens comuns.

\section{Referências}

Fontes Primárias:

Anonymi Londinensis ex Aristotelis Iatricis Menoniis et aliis medicis eclogue, hrsg. v. H. Diels, Suppl. Aristotel. III 1, Berlin, 1893. Acedido em 4 de Maio de 2014 http://cmg.bbaw.de/epubl/online/wa_anon_lond.html.

Aristóteles, Physiognomonica, eds. T. Loveday and E. S. Forster, Oxford: Claredon Press, 1913. . Problems II, trans. W. S. Hett, Loeb Classical Library. London / Cambridge: William Heinemann / Harvard University Press, 1957. . Politics, trans. H. Rackham, Loeb Classical Library. London / Cambridge: William Heinemann / Harvard University Press 1959. . Eudemian Ethics, Books I, II and VIII, trans. Michael Woods. Oxford: Clarendon Press, 1982. . The Complete Works of Aristotle: The Revised Oxford Translation, ed. J. Barnes. Princeton: Princeton University Press, 1984. . Poética, trad. Eudoro de Sousa, 4ed. Lisboa: INCM, 1986. . Retórica, trad. Manuel Júnior et al. In Obras Completas, vol. VIII. Lisboa: INCM, 2005.

. Partes dos Animais, trad. Maria Sousa e Silva. In Obras Completas, vol. IV, Lisboa: INCM, 2010.

. Sobre a Alma, trad. Ana Maria Lóio. In Obras Completas, vol. III, Lisboa: INCM, 2010.

Cícero, Tusculan Disputations, also treatises on The Nature of Gods and The Commonwealth, trans. C. D. Yonge. New York: Harper \& Brothers, 1888.

Hipócrates, Works of Hippocrates, 4 vols., trans. William H.S. Jones, Loeb Classical Library. London / Cambridge: William Heinemann / Harvard University Press, 1959.

Diógenes Laércio, Lives of Eminent Philosophers, 2 vols., trans. R. D. Hicks, Loeb Classical Library, Cambridge, Mass, and London: Harvard University Press and William Heinemann, 1925.

Teofrasto, Characters, ed. w/ intro., trans. and commentary by James Diggle. New York: Cambridge University Press, 2004. 
Platão, Euthyphro, Apology, Crito, Phaedo, Phaedrus, trans. Harold N. Fowler, Loeb Classical Library, London / Cambridge Mass.: William Heinemann / Harvard University Press, 1914.

. Ion. Or: On the Iliad, ed. w/ intr. Albert Rijkbaron, Amsterdam Studies in Classical Philology. Leiden / Boston: Brill, 2007.

.The Symposium, trans. M. C. Howatson. Cambridge: Cambridge University Press, 2008.

.Timeu-Critias, trad. e intro. Rodolfo Lopes. Coimbra, CECH: 2011.

Séneca, Anger, Mercy, Revenge, trans. Robert A. Kaster and Martha C. Nussbaum. Chicago and London: The University of Chicago Press, 2010.

Xenofonte, Memorabilia, Oeconomicus, Symposium, Apology, trans. E. C. Marchant and O. J. Todd, Loeb Classical Library, repr. ed. Cambridge Mass.: Harvard University Press, 1997 [1923].

Fontes Secundárias:

Bos, Jacques. "The rise and decline of character: humoral psychology in ancient and early modern medical theory", History of the Human Sciences, 3 (2009), 29-50.

Balsemão Pires, Edmundo. "Génio e Individuação", Revista Filosófica de Coimbra 40 (2011), 337-394.

Crowley, Timothy. “Aristotle's 'So-Called Elements”, Phronesis, 53 (2008), 223-242 .

Demont, Paul. "About philosophy and humoural medicine." Hippocrates in Context, ed. Philip J. van der Eijk. Leiden/Boston: Brill, 2005, 271-86.

. "L'ancienneté de la médecine hippocratique: un essai de bilan." Advances in Mesopotamian Medicine from Hammurabi to Hippocrates, eds. Annie Attia and Gilles Buisson. Leiden / Boston: Brill, 2009, 129-149.

Dodds, Eric R., The Greeks and the Irrational. Berkeley and Los Angeles: University of California Press, 1951.

Drabkin, Israel E. "Remarks on ancient psychopathology", Isis, 46 (1955), 223-234.

Edelstein, Ludwig, Ancient medicine: Selected papers of Ludwig Edelstein, eds. Owsei Temkin \& C. Lilian Temkin. Baltimore: the Johns hopkins Press, 1967 [1952].

Eijk, Philip J. van der, Medicine and Philosophy in Classical Antiquity. Doctors and Philosophers on Nature, Soul, Health and Disease. Cambridge: Cambridge University Press, 2005.

Flashar, Hellmut, Melancholie und Melancholiker in der medizinischen Theorien der Antike. Berlin: de Gruyter, 1966.

Flashar, Hellmut et Jouanna, Jacques, Médecine et morale dans l'antiquité : dix exposés suivis de discussions. Genève : Fondation Hardt, 1996.

Frede, Michael. "Philosophy and medicine in antiquity." Id., Essays in Ancient Philosophy. Minneapolis: University of Minnesota Press, 1987, 225-242.

Gill, Christopher. “Ancient Psychotherapy” Journal of the History of Ideas, 3 (1985), 307-325. 
Maria Elena Gorrini, "The Hippocratic Impact on Healing Cults: the archeological evidence in Attica", in: Hippocrates in Context, ed. Philip J. van der Eijk (Leiden/Boston: Brill, 2005), 135-156.

Hadot, Pierre. "Les divisions des parties de la philosophie dans l'Antiquité", $M u$ seum Helveticum, 36 (1979), 201-223.

Ivanovic-Zuvic, Fernando. "Consideraciones epistemológicas sobre la medicina y las enfermedades mentales en la Antigua Grecia", Revista Chilena de Neuro-Psiquiatría 3 (2004), 163-175.

Jackson, Stanley W., Melancholia and Depression. From Hippocratic Times to Modern Times. New Haven and London: Yale University Press, 1986.

. "A History of Melancholia and Depression." History of Psychiatry and Medical Psychology. With an Epilogue on Psychiatry and the Mind-Body Relation, ed. Edwin R. Wallace e John Gach. New York: Springer, 2009, 443-460.

Jaeger, Werner. "Aristotle's Use of Medicine as Model of Method in His Ethics", The Journal of Hellenic Studies, 11 (1957), 54-61.

. "A medicina como Paideia." Id., Paideia: A formação do homem grego, trad. Artur M. Pereira. Sao Paulo: Martins Fontes, 1986, 1001-1059.

Klibansky, Raymond et al., Saturn and Melancholy: Studies in the History of Natural Philosophy, Religion, and Art. Nendeln: Kraus, 1979 [1964].

Laskaris, Julie. "Error, loss, and change in the generation of therapies." Hippocrates in Context, ed. Philip J. van der Eijk. Leiden/Boston: Brill, 2005.

Laín Entralgo, Pedro, The Therapy of the Word in Classical Antiquity, trans. L. J. Rather and J. M. Sharp. New Haven: Yale University Press, 1970 [1958].

Liddell, Henry G. and Scott, Robert, Greek-English Lexicon, rev. by Henry Stuart Jones. Oxford: Clarendon Press, 1996.

Lloyd, Geoffrey E. R. "The role of medical and biological analogies in Aristotle's Ethics", Phronesis, 13 (1968), 68-83.

. Demystifying mentalities. Cambridge: Cambridge University Press, 1990.

. In the Grip of Disease. Studies in the Greek Imagination. Oxford: Oxford University Press, 2003.

Longrigg, James, Greek Rational Medicine: Philosophy and Medicine from Alcmaeon to the Alexandrians. New York: Routledge, 1993.

Manetti, Giovanni, Theories of the Sign in Classical Antiquity, trans. Christine Richardson. Bloomington and Indianapolis: Indiana University Press, 1993 [1987].

Morgan, Kathryn A. "Inspiration, recollection, and mimesis in Plato's Phaedrus" Ancient Models of Mind. Studies in Human and Divine Rationality, eds. Andrea Nightingale and David Sedley. New York: Cambridge University Press, 2010, 45-63.

Nussbaum, Martha Craven, The Therapy of Desire: Theory and Practice in Hellenistic Ethics. Princeton, NJ: Princeton University Press, 2009 [1994].

Nutton, Vivian Ancient Medicine. London: Routledge, 2004.

Pigeaud, Jackie. "Une physiologie de l'inspiration poétique, de l'humeur au trope", Les Etudes classiques, 46 (1978), 23-31. 
. La maladie de l'âme. Etude sur la relation de l'âme et du corps dans la tradition médico-philosophique antique (Paris: Les Belles Lettres, 1981). . "Prolégomènes à une histoire de la mélancolie", Histoire, Économie et Société, 4 (1984), 501-510.

Scarborough, John. "The Pharmacology of Sacred Plants, Herbs, and Roots." Magika Hiera. Ancient Greek Magic and Religion, eds. Christopher A. Faraone and Dirk Obbink (New York: Oxford University Press, 1991), 138-174.

Staden, Heinrich von. „Purity, Purification and Katharsis in Hippocratic Medicine.“ Katharsiskonzeptionen vor Aristoteles, hrsg. Martin Vöhler und Bernd Seidensticker. Berlin: de Gruyter, 2007, 21-51.

Steinebrunner, Bernd, Die Entzauberung der Krankheit. Vom Theos zum Anthropos - Über die alteuropäische Genesis moderner Medizin nach der Systemtheorie Niklas Luhmanns. Frankfurt a.M.: Peter Lang, 1987.

Steckerl, Fritz. "Plato, Hippocrates, and the 'Menon papyrus", Classical Philology, 40 (1945) 166-180.

Tieleman, Teun. "Nicomachean Ethics VII. 9 (1151 23) - 10: (In)Continence in Context." Aristotle: Nichomachean Ethics, Book VII Symposium Aristotelicum, ed. Carlo Natali. New York: Oxford University Press. 